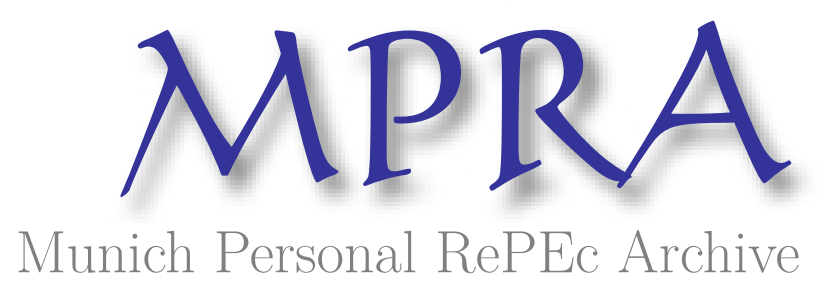

\title{
Juridical and financial considerations on the public recapitalisation and rescue of financial institutions during periods of financial crises (Part II)
}

\author{
Ojo, Marianne
}

Institute for Business Finance Research

9 September 2011

Online at https://mpra.ub.uni-muenchen.de/33265/

MPRA Paper No. 33265, posted 09 Sep 2011 14:19 UTC 


\begin{abstract}
In response to the recent Financial Crisis - after it had been widely accepted that "a serious disturbance in the economy of Member States" had occurred, and that several measures were required to remedy this disturbance, various Commission communications were adopted. The Communications include: The first Communication which (initially), was the only one that the Commission adopted intentionally: the Communication on the application of State aid rules to measures taken in relation to financial institutions in the context of the current global financial crisis (hereinafter "the Banking Communication").
\end{abstract}

However, faced with the pressure to issue more guidelines (such pressure being exerted by Member States), the Commission adopted three further Communications: the Communication on the re capitalisation of financial institutions in the current financial crisis: limitation of aid to the minimum necessary and safeguards against undue distortions of competition (hereinafter "the Recapitalisation Communication"); the Communication "On the treatment of impaired assets in the Community banking sector" (hereinafter, "the Toxic Assets Comunication") and finally, the Communication on the return to viability and the assessment of restructuring measures in the financial sector in the current crisis under the State aid rules (hereinafter "the Restructuring Communication")."

Whilst the Banking and Re capitalisation Communications constituted the focus of study in Part I to this paper, this paper will focus on the impact of shadow banking and Basel III on regulatory arbitrage, the corresponding need for greater transparency and disclosure within financial markets particularly within OTC markets, and impediments to the successful implementation of capital requirements which are aimed at fostering financial stability, coordination and harmonisation. Further, it will consider the extent to which regulators are prepared to deviate from regulations during the implementation of stress-testing and rescue programmes which are aimed at restoring stability to the financial system.

The redefinition of quantitative and qualitative standards for capital, in implementing the Supervisory Capital Assessment Programme (SCAP), as illustrated in the paper, should demonstrate the extent to which regulators, independent of shadow banking practices, are prepared to deviate from capital regulations under adverse scenarios where certain regulations prove to be unduly stringent.

Key Words: Financial Crisis, state aids, recapitalisation, regulatory arbitrage, shadow banking, Basel III, supervision, financial stability, OTC markets, counter party risks, stress testing, Supervisory Capital Assessment Program (SCAP), market discipline 


\section{Juridical and Financial Considerations on the Public Recapitalisation and Rescue of Financial Institutions During Periods of Financial Crises (Part II)*1}

\section{Introduction}

Financial Stability Measures, Counter Party Risks and the Shadow Banking System

„Over the past decade, the shadow banking system provided sources of inexpensive funding for credit by converting opaque, risky, long-term assets into money-like and seemingly riskless shortterm liabilities.“2

The risks posed by the operation of such instruments, vehicles and activities to financial stability, is not only evident by counter party risks which emanate from such complex and sophisticated instruments, the level of uncertainty attributed to lack of transparency within the financial markets, but also those risks inherent in the funding of maturities particularly those attributed to short term liabilities.

The shadow banking system has the potential to trigger systemic risks through the provision of credit, maturity and liquidity transformations - a situation which could arise where parts of the shadow banking system are able to function without "internalizing the true costs of its risks - hence gaining a funding advantage relative to banks where regulation aims to achieve such an internalization - which is likely to create opportunities for arbitrage that might undermine bank regulation and lead to a build up of additional leverage and risks in the system. ${ }^{63}$

As highlighted under the abstract, this paper, in constrast to Part I of the paper, will focus on rescue efforts, assessment and stress testing programmes which unintentionally, could result in the facilitation of regulatory arbitrage. Such efforts and other initiatives being primarily promulgated as measures aimed at facilitating financial stability. Whilst the new Basel III framework is highly commended, debates have also arisen in relation to whether it could trigger as many problems as those which it has been designed to rectify. Nevertheless, this paper will highlight why it is crucial to ensure that the goals, objectives and initiatives of Basel III in promoting financial stability -

1 Paper to be presented at the 2012 IBFR (Institute for Business \& Finance Research) COSTA RICA CONFERENCIA/ CONGRESO GLOBAL ADMINISTRACION Y FINANZAS SAN JOSE, COSTA RICA: MAYO 22-25, 2012. For further details on the Conference, please visit http://www.theibfr.com/costaricaesp.htm

2 See Zoltan Pozsar, Tobias Adrian, Adam Ashcraft, and Hayley Boesky, „Shadow Banking“ Staff Report No 458 July 2010, Federal Reserve Bank of New York http://www.newyorkfed.org/research/staff_reports/sr458.pdf at page 2 of 81 (abstract of the paper). Shadow banking is considered to comprise of , financial intermediaries that conduct maturity, credit, and liquidity transformation without access to central bank liquidity or public sector credit guarantees. Examples of shadow banks include finance companies, asset-backed commercial paper (ABCP) conduits, limited-purpose finance companies, structured investment vehicles, credit hedge funds, money market mutual funds, securities lenders, and government-sponsored enterprises." see ibid.

3 "The provision of maturity/liquidity transformation and leverage could make credit intermediation by non bank entities "bank-alike" and raise concerns for authorities to the extent that they create systemic risks." See Financial Stability Board, „Shadow Banking: Scoping the Issues (A Background Note of the Financial Stability Board) http://www.financialstabilityboard.org/publications/r_110412a.pdf at page 3 (page 5 of 11) 
particularly its focus on macro prudential stability, are not undermined.

Recapitalisation and rescue schemes, as well as other financial stability plans and programmes, whilst aiming to restore financial stability through the most effective and least time consuming means, should also take into account other important considerations such as the objectives and intent of certain regulations - particularly those which not only embrace the same goals of the attainment of financial stability, but also other vital goals of harmonisation, coordination between different jurisdictions. Basel III provides an excellent example of such as regulation. Where the implementation of certain programmes in exceptional scenarios result in deviations from key regulations, the danger that regulatory arbitrage practices will be facilitated not only exists, but also the likelihood that lack of coordination and harmonisation will occur across jurisdictions.

This paper will highlight the fact that exceptional situations have resulted in derogations from certain norms - however such deviations could be justified in certain cases - particularly in view of the importance attached to the goal of achieving speedy financial recovery as well as where these situations are intended to be one-off scenarios. Emergency legislation designed to address short term and serious disruptions to the economy/adverse scenarios, or unprecedented deviations from the norm under adverse scenarios, it should be pointed out, should also be distinguished from rampant practices deliberately aimed at circumventing key and/or not so central capital legislation.

The paper commences with a section which is aimed at underlining the importance of stress tests in promoting transparency and disclosure across the financial markets - such measures aimed at facilitating market discipline. The section will also introduce types of regulatory arbitrage which which are likely to result in the circumvention of capital requirements designed to ,manage linkages and prudently conduct negotiations" between vital financing channels.

Section two then elaborates on rescue and financial stability measures which have been implemented in the European Union, as well as the United States. The section also re-iterates certain observations drawn from the first part to the paper - whereby a more lenient stance has been adopted by the Commission as a means of ensuring that the all important goal of avoiding ,serious disturbances to the economy of Member States" is attained. This scenario, being peculiar to the EU, is then used as the building block for the next section (section three) which will address the exceptional scenarios whereby supervisors in the US have deviated from standard capital requirements. Within this context, the implementation of the Supervisory Capital Assessment Program (SCAP), comprising the 2009 stress tests which constituted a "special forward-looking assessment exercise" to "evaluate expected losses and the resources to absorb those losses" will be considered. The section will also aim to deduce whether one-off deviations by supervisors during the implementation of the SCAP could be justified - where such deviations imply derogations from key legislation such as the Basel Accords.

Concerns attributed to the new Basel III framework relate to its "facilitation of the shadow banking system whilst constraining the bank sector." "The new, more stringent capital and liquidity requirements introduced through Basel III are likely to impact the more highly regulated banking sector since it is likely that there will be greater incentives to transact in less stringent regulated sectors such as the shadow banking system or through less stringent regulated capital instruments.

In concluding the paper, the final section will also highlight why coordination and harmonisation are central to the goal of mitigating regulatory arbitrage practices.

4 See BRIEF, „Deutsche Bank CFO Says Concerned New Basel Rules Allow Shadow Banking System Whilst Constraining Bank Sector“ < http:/www.finanznachrichten.de/nachrichten-2011-05/20264700-briefdeutsche-bankcfo-says-concerned-new-basel-rules-allow-shadow-banking-system-020.htm 
"In order to ensure financial stability, the Commission should review and report on measures to enhance the transparency of OTC markets, to mitigate the counterparty risks and more generally to reduce the overall risks, such as by clearing of credit default swaps through central counterparties (CCPs). The establishment and development of CCPs in the EU subject to high operational and prudential standards and effective supervision should be encouraged. The Commission should submit its report to the European Parliament and the Council together with any appropriate proposals, taking into account parallel initiatives at the global level as appropriate., ${ }^{5}$

Stress testing not only serves as an important risk management tool - particularly for counter party risk management, ${ }^{6}$ but has also been identified as a means whereby investors' uncertainty about the quality of bank balance sheets could be eliminated. ${ }^{7}$

In addition to the trading book and securitisation reforms announced in July 2009, the Basel Committee on Banking Supervision proposed the consolidation of the capital requirements for counterparty credit risk exposures arising from derivatives and securities financing activities.

These enhancements are aimed at strengthening the resilience of individual banking institutions and reducing the risk of shocks being transmitted from one institution to another through the derivatives and financing channel. Consolidated counterparty capital requirements should increase incentives to transfer OTC derivative exposures to central counterparties and exchanges.

However, three forms of arbitrage which are likely to result in the circumvention of capital requirements designed to „manage linkages and prudently conduct negotiations“ between channels, broker-dealer and asset management subsidiaries, as well as credit intermediation have been identified as follows:

- Cross border regulatory systems arbitrage

- Regulatory tax and economic capital arbitrage

- Ratings arbitrage.

These forms of arbitrage, as identified by Pozsar et al, are also considered by them to have emerged from: ${ }^{8}$ i) the fractured nature of the global financial regulatory framework, ii) the dependence of capital adequacy rules (Basel II) on credit ratings and iii),,a collection of one - off, uncoordinated decisions by accounting and regulatory bodies regarding the accounting and regulatory capital

5 See DIRECTIVE 2009/111/EC OF THE EUROPEAN PARLIAMENT AND OF THE COUNCIL of 16 September 2009 amending Directives 2006/48/EC, 2006/49/EC and 2007/64/EC as regards banks affiliated to central institutions, certain own funds items, large exposures, supervisory arrangements, and crisis management at page 5 of 23.

6 See Bank for International Settlements, Consultative Document, „Strengthening the Resilience of the Banking Sector, at page 48

7 See also European Commission, „"Economic Crisis in Europe: Causes, Consequences and Responses, section 3.2.1 Crisis Resolution Policies: Stress Testing of Banks" $<$

http://ec.europa.eu/economy_finance/publications/publication15887_en.pdf > It is also highlighted in the report that stress tests could serve as "decisive tools in accomplishing this task since they provide information about banks" resilience and ability to absorb possible shocks."

8 Z Pozsar et al, „Shadow Banking“ Staff Report No 458 July 2010, Federal Reserve Bank of New York at pages 37 and 38 of 81 (pages 29 and 30). http://www.newyorkfed.org/research/staff_reports/sr458.pdf 
treatment of certain exposures , lending and asset manegment activities.“

Further evidence which may or may not justify a deviation from standard capital requirements will be considered under section $\mathrm{C}$ by way of reference to the Supervisory Capital Assessment Programme - a programme which was initiated in February 2009 as a means of assessing capital needs of banking institutions as well as restoring financial stability back to the US financial system and markets following the devastating consequences and impact of the Financial Crisis which was triggered in 2007. Such a programme will be contrasted with other proposals relating to forward looking provisions.

\section{B. Consideration of Adverse Scenarios and Serious Disruptions to the Economy.}

Several stages were identified by the Commission in its Communication ${ }^{9}$ as phases through which the route from financial instability to financial stability are to be achieved. These are as follows:

i) Stabilisation of the Crisis

ii) Restructuring the banking sector

iii) Hand-over of banks to the private sector at some stage in the future

Certain financial stability and rescue measures which have been implemented by various jurisdictions all share the common feature of the more relaxed and flexible attitude which governments and supervisors have demonstrated where urgent and exceptional decisions need to be instigated to restore confidence and stability back to the financial system.

As highlighted in the predecessor to this paper (Part One) ${ }^{10}$ the Commission's resort to the "rarely used and more lenient provision of Article 87(3)(b) EC Treaty, during the recent Financial Crisis, to authorise national recovery plans and individual rescue measures" ${ }^{\prime 11}$ is an explicit illustration of its commitment to goals aimed at facilitating economic stability through the aversion of " a serious disturbance in the economy of Member States." Its realisation of the need to implement this provision occurred after Lehman Brothers filed for bankruptcy - the first case to be decided under Article 87(3)(b) EC Treaty being Bradford and Bingley.

In respect of Northern Rock, and with respect to the legal basis of the Commission's decisions, the rescue decision and the decision of 2 April 2008 to open the formal investigation procedure, were taken on the basis of Article 87(3)(c) of the Treaty and the Rescue and Restructuring Guidelines the reason for this being that the Commission considered the difficulties faced by Northern Rock to be linked specifically to Northern Rock - therefore not justifying the application of Article 87(3)(b) of the Treaty.

As the severity of the Financial Crisis affected more and more banks, in September 2008, the Commission considered the application of Article 87(3)(b) EC Treaty, to banks that were in receipt of State aid, to be necessary thereafter.

9 See European Commission, Communication from the Commission From Financial Crisis to Recovery: A European Framework for Action at page 329.10 .2008 COM (2008) 706 final $<$ http://eurlex. europa.eu/LexUriServ/LexUriServ.do?uri=COM:2008:0706:FIN:EN:PDF>

10 See Rodriguez - Miguez J and Ojo M, "Juridical and Financial Considerations on the Public Re Capitalisation and Rescue of Financial Institutions During Periods of Financial Crisis” and also M Ojo, „Central Banks and Different Policies Implemented in Response to the Recent Financial Crisis“"

11 See D Gerard, „Managing the Financial Crisis in Europe: Why Competition Law is Part of the Solution, Not of the

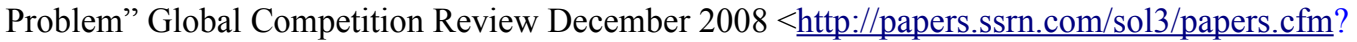

abstract_id=1330326> at page 6 
In the United States, public recapitalisation served as a general means of confronting the Financial Crisis. As noted under Part I to this paper, under preliminary and substantive observations, it must be highlighted that competition (Antitrust) considerations have not been taken into account in contrast to European State Aids instruments which serve as an essential component of European Competition Law.

On October 14 2008, the following ,watershed“ measures aimed at rescuing the ailing U.S. Markets were announced by the U.S. Treasury, Federal Reserve and FDIC:

- the Capital Purchase Programme"

- the FDIC Temporary Liquidity Guarantee Program

- the Federal Reserve's Commercial Paper Funding Facility

Another national recovery plan, the Supervisory Capital Assessment Program (SCAP), comprised the 2009 stress tests which constituted a "special forward-looking assessment exercise" to "evaluate expected losses and the resources to absorb those losses" if economic conditions deteriorated worse than generally expected. ${ }^{12}$

The European Banking Federation (EBF), is supportive of the provisioning based on Expected Loss model and recommended a provisioning model based on the EL concept, which "captures the economic reality of the lending activities of financial institutions in line with the six principles of the Bank for International Settlements" in order to achieve sound Expected Loss provisioning approach. ${ }^{13}$

\section{The Supervisory Capital Assessment Program (SCAP): A Deviation from Basel Capital Rules?}

This section attempts to highlight the fact that whilst supervisors still consider capital regulations to be unduly stringent under adverse conditions, such stringency has been increased with the introduction of Basel III. Basel III is not intended to make life more difficult for banks or bank holding companies - Basel III's more stringent nature is largely attributed to the much urgently needed response to the recent Financial Crisis. However, it appears that even greater deviation from capital rules will occur following the introduction of Basel III - than was the case with Basel II.

Basel III not only embraces a micro prudential framework (an enhanced Basel II) which is aimed at:

- Increasing the quality of, as well as improving the quantity of capital;

- Enhancing risk managment and disclosure;

- Introducing a leverage ratio to supplement risk-weighted measures,

- Addressing counterparty credit risk generated through Over-the-Counter derivatives;

12 „The Capital Assistance Program not only aimed at assessing capital needs via comprehensive stress tests of major banking institutions, but also ensuring that any projected capital shortfalls were met by private investors and, if necessary, government infusions.“ See AE Wall, „Stress Tests and Market Discipline“ Banking and Financial Services Policy Report Volume 30 No 9 September 2011 at page 2. See also US Department of the Treasury, Treasury White Paper: The Capital Assistance Program and Its Role in the Financial Stability Plan 2 (Feb. 23, 2009) [hereinafter Treasury White Paper].

13 European Banking Federation, Comments on consultative documents issued by Basel Committee on Banking Supervision "Strengthening the Resilience of the Banking Sector" and "International Framework for Liquidity Risk Measurement, Standards and Monitoring" at page 6

$<$ http://www.finansraadet.dk/media/208544/ebf_hoeringssvar_international_framework_for_liquidity_risk_measu rement_standards_and_monitoring_150410.pdf > 
but also a macro prudential component which is designed to address stability over time (procyclicality) - through counter cyclical capital charges and forward looking provisioning, capital conservation rules for strongercapital buffers; and stability at each point in time. ${ }^{14}$

Providing for adverse scenarios and in their assessment of whether bank holding companies had sufficient ${ }^{15}$ capital to absorb losses under such advserse conditions, the degree and extent to which supervisors were prepared to deviate from standard capital rules in their implementation of SCAP, is illustrated thus: ${ }^{16}$

- Supervisors were not content with the traditional definition of Tier 1 risk-based capital, focusing instead on "Tier 1 common capital" or that percentage of Tier 1 capital that is common equity.

- Supervisors traditionally preferred common stockholders' equity and mandated it be the majority component of Tier 1 capital, but SCAP marked the first time supervisors defined a minimum amount of Tier 1 capital that must be comprised of common equity. ${ }^{17}$

- After redefining the qualitative standards for capital they would use for SCAP, supervisors then established a new quantitative standard: under the adverse scenario, BHCs subject to SCAP would need a Tier 1 capital buffer of at least $6 \%$ and Tier 1 common capital buffer of at least four percent at year-end 2010. Previously BHCs were only required to maintain a minimum Tier 1 capital buffer of four percent, although supervisors generally expected BHCs to maintain capital levels in excess of the minimum standard." ${ }^{\text {18 }}$

The composition of Tier 1 capital, as prescribed by regulation and evidenced by the Basel Committee's efforts aimed at improving the quality of capital, is illustrated in the table below: ${ }^{19}$

14 ,The stability at each point in time component comprises of systemic capital surcharges for systemically important financial institutions and the identification of interlinkages and common exposures among all financial institutions, as well as the systemic oversight of OTC derivatives. See H Hannoun, „Towards a Global Financial Stability Framework“ Bank for International Settlements Publications, page 906 $<$ http://www.bis.org/speeches/sp100303.pdf $>$

15 Supervisors' focus being on „both the amount and composition of capital held by each of the BHCs.“

16 See AE Wall, „Stress Tests and Market Discipline“ Banking and Financial Services Policy Report Volume 30 No 9 September 2011 at page 5 .

17 „This revised emphasis on common equity being justified as follows:The SCAP's emphasis on what is termed “Tier 1 Common capital" reflects the fact that common equity is the first element of the capital structure to absorb losses, offering protection to more senior parts of the capital structure and lowering the risk of insolvency. All else equal, Tier 1 Common capital gives a BHC greater permanent loss absorption capacity and greater ability to conserve resources under stress by changing the amount and timing of dividends and other distributions." see ibid.

18 ,Supervisors stressed these were not new capital standards, but rather a "onetime buffer [that] will give market participants, as well as the firms themselves, confidence in the capacity of the major BHCs to perform their critical role in lending, even if the economy proves weaker than expected." see ibid.

19 Source: See H Hannoun, „,Towards a Global Financial Stability Framework“ Bank for International Settlements Publications, page 11 of $26<\mathrm{http}: / /$ www.bis.org/speeches/sp100303.pdf> 


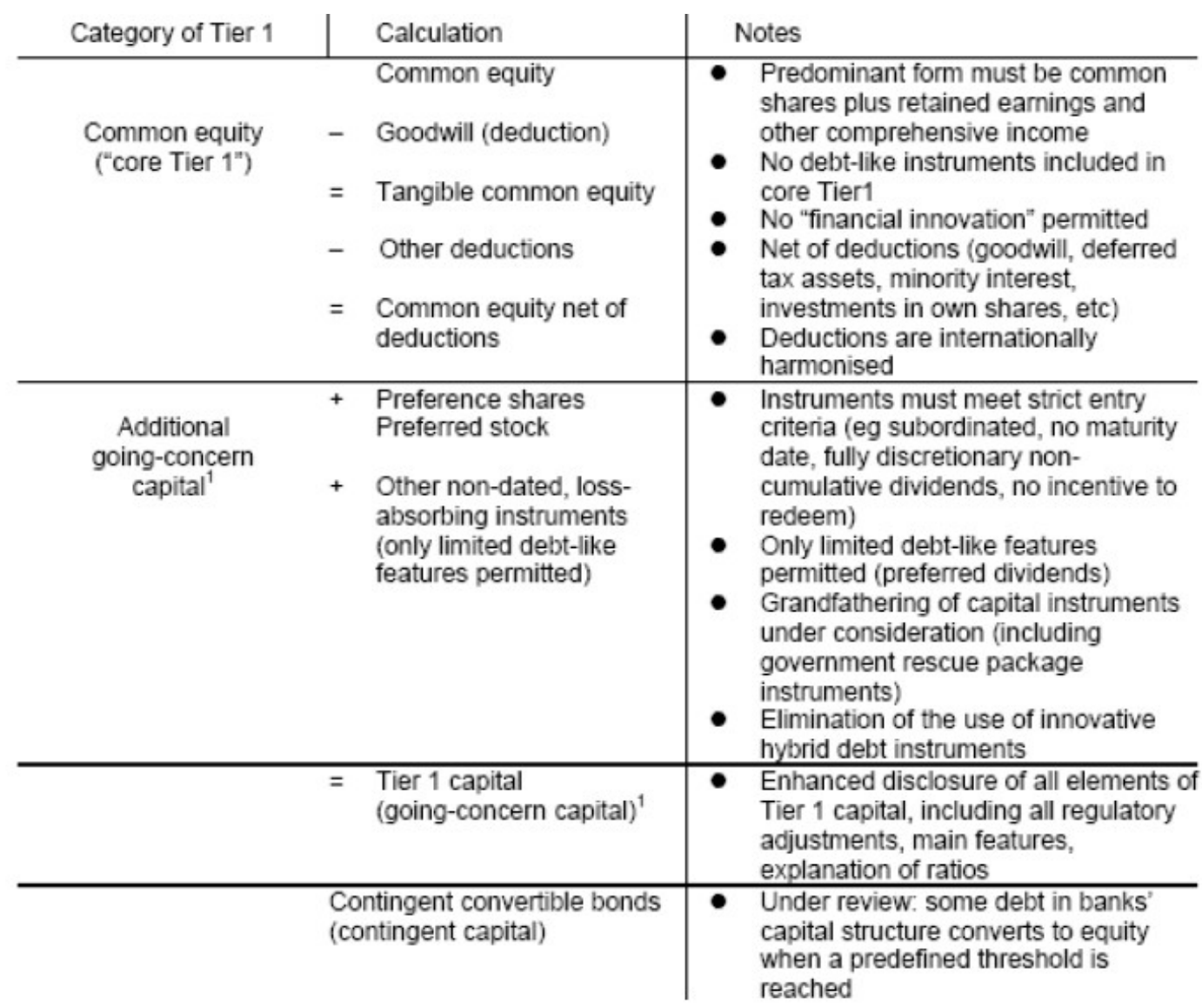

According to Wall, ${ }^{20}$ through the exclusion of preferred equity, supervisors ensured dividend payments would not unnecessarily deplete earnings, whilst also excluding the preferred equity received by the US government via the TARP ${ }^{21}$ capital infusions made in 2008.

In assessing whether supervisors' decisions to exclude preferred equity is justified, consideration must be had to regulatory aims and objectives of the reformed rules - as embodied by the Basel III framework. A general criticism of Basel I relates to the fact that it promoted capital arbitrage. This is attributed to its wide risk categories which provide banks with the liberty to "arbitrage between their economic assessment of risk and the regulatory capital requirements."22 Hence Basel II was introduced to address such (and other) deficiencies of the original Basel Accord. Should a deviation from Basel capital rules imply further evidence of its unduly stringent regulations? To what extent is a deviation from such stringency justified in adverse conditions?

20 AE Wall, „Stress Tests and Market Discipline“ Banking and Financial Services Policy Report Volume 30 No 9 September 2011 at page 5

21 The US Treasury's interest in purchasing non-performing assets from major financial institutions was formalized as the Troubled Asset Relief Program (TARP) which was included in the bill for the Emergency Economic Stabilization Act (EESA). See T Hoshi and A K Kashyap, "Will the U.S. Bank Recapitalization Succeed? Eight Lessons from Japan“ NBER Working Paper No. 14401 August 2009 at page 6. „Section 101 of EESA establishes the now well-known Troubled Asset Relief Program ("TARP”) and authorizes the Treasury to purchase, and to make and fund commitments to purchase, troubled assets from financial institutions up to an amount not exceeding $\$ 700$ billion outstanding at any one time, as adjusted for the operation of the companion guarantee program." See „TARPOONED: The Recapitalization of the US Financial Industry „October 16, 2008 Dewey and LeBoeuf Publications <http://www.dl.com> pages 2 and 3 of 18

22 'Capital Requirements and Bank Behaviour: The Impact of the Basel Accord' Basel Committee on Banking Supervision Working Papers April 1999 at page 21 
Whilst the exclusion of preferred equity in certain exceptional situations may be justified, such a practice nevertheless, may encourage regulatory arbitrage whilst undermining the aims and objectives of regulatory capital frameworks. To what extent should deviations from the norm be permitted during adverse conditions? Should all banks be rescued? - in the same way as countries in need of bail outs are automatically granted aids?

The answer to this appears to be in the affirmative - where the sustenance of a bank/bank holding company or a Member State is crucial to the goals of financial stability of an economy or a Union, then necessary and exceptional ,emergency“ measures may need to be implemented to prevent disastrous economic consequences. The world in which we live today has been dramatically transformed in the advent of globalisation, conglomeration, information technology, innovation, the growth of complex derivative products and competition. Factors which contribute to the increased susceptibility of systemic risks.

Such emergency measures, naturally, are intended, and hopefully are presumed to be „one-offs.“ Longer term plans for financial stability which are designed to prevent the re-occurrence of further future „emergency scenarios“ - if necessary and possible, will also require consideration.

A re definition of and deviation from standard capital rules in one-off scenarios may be permitted where such „circumvention“ does not deviate to a significant extent - however where such deviation is capable of resulting in possible distortions and impediments in respect of efforts aimed at fostering harmonisation, coordination, as well as other regulatory aims, such practices should be discouraged. The re definition of qualitative as well as quantitative standards for capital, as highlighted by Wall, in the implementation of the SCAP, may appear to constitute a significant deviation from the usual methodology - however this could also be permitted in adverse scenarios which occur on a one-off basis. A significant degree of judgement is involved in such an implementation and this constitutes a reason why the SCAP has attracted criticisms.

\section{Conclusion}

Concerns attributed to the new Basel III framework relate to its "facilitation of the shadow banking system whilst constraining the bank sector." 23 The new, more stringent capital and liquidity requirements introduced through Basel III are likely to impact the more highly regulated banking sector since it is likely that there will be greater incentives to transact in less stringent regulated sectors such as the shadow banking system or through less stringent regulated capital instruments.

The redefinition of quantitative and qualitative standards for capital, in implementing the Supervisory Capital Assessment Programme (SCAP), as illustrated in the paper, demonstrates how regulators, independent of shadow banking practices, are prepared to deviate from standard capital regulations under adverse scenarios where such regulations prove to be too stringent.

Whilst ongoing debates persist in relation to whether Basel III will exacerbate more problems than those which it is intended to rectify, ${ }^{24} \mathrm{a}$,circumvention“ of Basel III rules in exceptional cases - as

23 See BRIEF, „Deutsche Bank CFO Says Concerned New Basel Rules Allow Shadow Banking System Whilst Constraining Bank Sector" < http://www.finanznachrichten.de/nachrichten-2011-05/20264700-briefdeutsche-bankcfo-says-concerned-new-basel-rules-allow-shadow-banking-system-020.htm

24 See Allen, William A., Chan, Ka Kei, Milne, Alistair K. L. and Thomas, Steve H., Basel III: Is the Cure Worse than the Disease? (September 30, 2010) and also Ojo M, „Preparing for Basel IV (whilst commending Basel III) : Why liquidity risks still present a challenge to regulators in prudential supervision ( Part II)“ http://mpra.ub.uni- 
determined by regulators, is also likely to facilitate regulatory arbitrage. As highlighted under a previous paper, ${ }^{25}$ central banks' expertise and the vital roles they assume will be required in facilitating the objectives of mitigating systemic risks, effective coordination and communication between regulators and supervisors, as well as the mitigation of regulatory arbitrage. Further, the mitigation of systemic risks through the redress of shadow banking channels which could facilitate regulatory arbitrage practices, as well as the efficient functioning of new macro prudential frameworks will help ensure that new Basel III standards' objectives to facilitate greater financial stability on a macro prudential basis are not undermined by possibilities and gaps which could foster capital arbitrage and the building up of systemic risks. and Stringent Basel III Regulations „, Available at SSRN: http://ssrn.com/abstract=1859543 and http://mpra.ub.unimuenchen.de/31319/ 


\section{REFERENCES}

Allen, William A., Chan, Ka Kei, Milne, Alistair K. L. and Thomas, Steve H., Basel III: Is the Cure Worse than the Disease? (September 30, 2010)

Bank for International Settlements, Consultative Document, „Strengthening the Resilience of the Banking Sector

Basel Committee on Banking Supervision, 'Capital Requirements and Bank Behaviour: The Impact of the Basel Accord’ Basel Committee on Banking Supervision Working Papers April 1999

BRIEF, „Deutsche Bank CFO Says Concerned New Basel Rules Allow Shadow Banking System Whilst Constraining Bank Sector“ < http://www.finanznachrichten.de/nachrichten-201105/20264700-briefdeutsche-bank-cfo-says-concerned-new-basel-rules-allow-shadow-bankingsystem-020.htm

DIRECTIVE 2009/111/EC OF THE EUROPEAN PARLIAMENT AND OF THE COUNCIL of 16 September 2009 amending Directives 2006/48/EC, 2006/49/EC and 2007/64/EC as regards banks affiliated to central institutions, certain own funds items, large exposures, supervisory arrangements, and crisis management.

European Banking Federation, Comments on consultative documents issued by Basel Committee on Banking Supervision "Strengthening the Resilience of the Banking Sector" and "International Framework for Liquidity Risk Measurement, Standards and Monitoring" $<$ http://www.finansraadet.dk/media/208544/ebf_hoeringssvar_international_framework_for_liquidit y_risk_measurement_standards_and_monitoring__150410.pdf

European Commission, „"Economic Crisis in Europe: Causes, Consequences and Responses, section 3.2.1 Crisis Resolution Policies: Stress Testing of Banks" $<$ http://ec.europa.eu/economy_finance/publications/publication15887_en.pdf >

European Commission, Communication from the Commission_From Financial Crisis to Recovery: A European Framework for Action at page 3 29.10.2008 COM (2008) 706 final $<$ http://eurlex. europa.eu/LexUriServ/LexUriServ.do?uri=COM:2008:0706:FIN:EN:PDF>

Financial Stability Board, „Shadow Banking: Scoping the Issues (A Background Note of the Financial Stability Board) http://www.financialstabilityboard.org/publications/r_110412a.pdf

Gerard D, „Managing the Financial Crisis in Europe: Why Competition Law is Part of the Solution, Not of the Problem" Global Competition Review December 2008

$<\underline{\text { http://papers.ssrn.com/sol3/papers.cfm?abstract id }=1330326>}$

Hannoun H, „Towards a Global Financial Stability Framework“ Bank for International Settlements Publications, page 9 of $26<\mathrm{http}: / /$ www.bis.org/speeches/sp100303.pdf $>$

Hoshi T and Kashyap AK, "Will the U.S. Bank Recapitalization Succeed? Eight Lessons from Japan“ NBER Working Paper No. 14401 August 2009 
Ojo M, „Central Banks and Different Policies Implemented in Response to the Recent Financial Crisis“"

Ojo M, „Preparing for Basel IV (whilst commending Basel III) : Why liquidity risks still present a challenge to regulators in prudential supervision ( Part II)“ http://mpra.ub.uni-muenchen.de/32630/ and http://papers.ssrn.com/sol3/papers.cfm?abstract_id=1732304

Ojo M, „Financial Stability, New Macro Prudential Arrangements and Shadow Banking: Regulatory Arbitrage and Stringent Basel III Regulations ,, Available at SSRN:

http://ssrn.com/abstract=1859543 and http://mpra.ub.uni-muenchen.de/31319/

Rodriguez - Miguez J and Ojo M, "Juridical and Financial Considerations on the Public Re Capitalisation and Rescue of Financial Institutions During Periods of Financial Crisis"

„TARPOONED: The Recapitalization of the US Financial Industry „October 16, 2008 Dewey and LeBoeuf Publications <http://www.dl.com>

US Department of the Treasury, Treasury White Paper: The Capital Assistance Program and Its Role in the Financial Stability Plan 2 (Feb. 23, 2009)[hereinafter Treasury White Paper].

Wall AE, „Stress Tests and Market Discipline“ Banking and Financial Services Policy Report Volume 30 No 9 September 2011

Zoltan Pozsar, Tobias Adrian, Adam Ashcraft, and Hayley Boesky , „Shadow Banking“ Staff Report No 458 July 2010, Federal Reserve Bank of New York http://www.newyorkfed.org/research/staff_reports/sr458.pdf 

MEMO/10/284

Brussels, 29 June 2010

State aid: Overview of national measures adopted as a response to the financial/economic crisis

(See table attached in annex)

This information is compiled from a range of sources and is provided for information only. The European Commission cannot confirm the completeness or accuracy of the information. 


\section{Communications from the Commission to provide guidance to Member States}

Communication from the Commission - The application of State aid rules to measures taken in relation to financial institutions in the context of the current global financial crisis, 13 October 2008 (see $\underline{\mathrm{IP} / 08 / 1495}$ )

Communication from the Commission - The recapitalisation of financial institutions in the current financial crisis: limitation of aid to the minimum necessary and safeguards against undue distortions of competition, 5 December 2008 (see IP/08/1901)

Communication from the Commission on the Treatment of Impaired Assets in the Community Banking Sector, 25 February 2009 (see $\underline{\mathrm{IP} / 09 / 322}$ )

Communication from the Commission - Temporary framework for State aid measures to support access to finance in the current financial and economic crisis, adopted on 17 December 2008 (see IP/08/1993), as amended on 25 February 2009.

Communication from the Commission - The return to viability and the assessment of restructuring measures in the financial sector in the current crisis under the State aid rules, 23 July 2009 (see IP/09/1180)

\section{State aid cases - situation as of 29 June 2010}

Decisions adopted by the Commission in 2008/2009/2010

\section{AUSTRIA}

\begin{tabular}{|c|c|c|}
\hline Type of measure / Beneficiary & Type of Decision & Date of adoption \\
\hline $\begin{array}{l}\text { N557/2008 - Aid scheme for the Austrian } \\
\text { financial sector (guarantees, recapitalisation \& } \\
\text { other) }\end{array}$ & $\begin{array}{l}\text { Decision not to raise objections } \\
\underline{\mathrm{IP} / 08 / 1933}\end{array}$ & 09 December 2008 \\
\hline N352/2009 - Prolongation & MEX/09/0630 & 30 June 2009 \\
\hline N663/2009 - Second prolongation & MEX/09/1217 & 17 December 2009 \\
\hline N241/2010 - Extension & $\underline{\mathrm{IP} / 10 / 839}$ & 25 June 2010 \\
\hline N214/2008 - Recapitalisation of Hypo Tirol & $\begin{array}{l}\text { Decision not to raise objections } \\
\text { IP/09/928 }\end{array}$ & 17 June 2009 \\
\hline $\begin{array}{l}\text { N 640/2009 - BAWAG - capital injection and } \\
\text { asset guarantee }\end{array}$ & $\begin{array}{l}\text { Decision not to raise objections } \\
\underline{\mathrm{IP} / 09 / 1989}\end{array}$ & 22 December 2009 \\
\hline $\begin{array}{l}\text { C } 16 / 2009+\text { N698/2009 - Emergency aid to } \\
\text { Hypo Group Alpe Adria }\end{array}$ & $\begin{array}{l}\text { Decision not to raise objections } \\
\underline{\mathrm{IP} / 09 / 1998}\end{array}$ & 23 December 2009 \\
\hline
\end{tabular}

\footnotetext{
${ }^{1}$ As a general rule, aid schemes are reviewable six months after approval. Some individual decisions are subject to a review and possible restructuring plan.
} 
Belgium

Belgium/Luxembourg

\begin{tabular}{|l|l|r|}
\hline $\begin{array}{l}\text { NN45-49-50/2008 - Guarantee on liabilities of } \\
\text { Dexia }\end{array}$ & $\begin{array}{l}\text { Decision not to raise objections } \\
\mathrm{IP} / 08 / 1745\end{array}$ & 19 November 2008 \\
\hline Prolongation & $\underline{\mathrm{IP} / 09 / 1662}$ & 30 October 2009 \\
\hline
\end{tabular}

\section{Belgium/France/Luxembourg}

\begin{tabular}{l|l|r|}
\hline $\begin{array}{l}\text { C9/2009 - Guarantee in favour of Dexia on } \\
\text { certain assets in FSA }\end{array}$ & $\begin{array}{l}\text { Decision not to raise objections } \\
\mathrm{IP} / 09 / 399\end{array}$ & 13 March 2009 \\
\hline
\end{tabular}

\section{Belgium/Luxembourg/Netherlands}

\begin{tabular}{|l|l|c|}
\hline N574/2008 - Measures in favour of Fortis & $\begin{array}{l}\text { Decision not to raise objections } \\
\underline{\mathrm{IP} / 08 / 1746}\end{array}$ & 19 November 2008 \\
\hline $\begin{array}{l}\text { NN42-46-53A/2008 - Restructuring aid to Fortis } \\
\text { Bank and Fortis Bank Luxembourg }\end{array}$ & $\begin{array}{l}\text { Decision not to raise objections } \\
\underline{\underline{\mathrm{IP} / 08 / 1884}}\end{array}$ & 03 December 2008 \\
\hline
\end{tabular}

\section{Belgium/Luxembourg}

\begin{tabular}{l|l|r|}
\hline $\begin{array}{l}\text { N255/2009 and N274/2009 - Additional aid } \\
\text { measures in favour of Fortis Bank and Fortis } \\
\text { Bank Luxembourg }\end{array}$ & $\begin{array}{l}\text { Decision not to raise objections } \\
\underline{I P / 09 / 743}\end{array}$ & 12 May 2009 \\
\hline
\end{tabular}

\section{Belgium}

\begin{tabular}{|l|l|r|}
\hline $\begin{array}{l}\text { N602/2008 - Recapitalisation measure in favour } \\
\text { of KBC }\end{array}$ & $\begin{array}{l}\text { Decision not to raise objections } \\
\underline{\mathrm{IP} / 08 / 2033}\end{array}$ & 18 December 2008 \\
\hline NN57/2008 - Capital Injection for Ethias Group & $\begin{array}{l}\text { Decision not to raise objections } \\
\underline{\mathrm{IP} / 09 / 254}\end{array}$ & 12 February 2009 \\
\hline $\begin{array}{l}\text { C18/2009 - Recapitalisation and asset relief for } \\
\text { KBC Group }\end{array}$ & $\begin{array}{l}\text { Decision not to raise objections } \\
\underline{\underline{I P} / 09 / 1063}\end{array}$ & 30 June 2009 \\
\hline $\begin{array}{l}\text { C18/2009 - Asset relief and restructuring } \\
\text { package for KBC }\end{array}$ & $\begin{array}{l}\text { Final conditional decision after } \\
\text { formal investigation procedure } \\
\text { IP/09/1730 }\end{array}$ & 18 November 2009 \\
\hline N 256/2009 - Restructuring aid for Ethias & $\begin{array}{l}\text { Decision not to raise objections } \\
\underline{\mathrm{IP} / 10 / 592}\end{array}$ & 20 May 2010 \\
\hline
\end{tabular}

\section{Belgium/France/Luxembourg}

\begin{tabular}{|l|l|c|}
\hline $\begin{array}{l}\text { C9/2009 - Approval of restructuring plan for } \\
\text { Dexia }\end{array}$ & $\begin{array}{l}\text { Final conditional decision after } \\
\text { formal investigation procedure } \\
\underline{\mathrm{P} / 10 / 201}\end{array}$ & 26 February 2010 \\
\hline
\end{tabular}

\section{CYPRus}

\begin{tabular}{|l|l|r|}
\hline $\begin{array}{l}\text { N511/2009 - Cypriot scheme to support credit } \\
\text { institutions (guarantee) }\end{array}$ & $\begin{array}{l}\text { Decision not to raise objections } \\
\underline{\underline{P} / 09 / 1569}\end{array}$ & 22 October 2009 \\
\hline
\end{tabular}




\section{DENMARK}

\begin{tabular}{|c|c|c|}
\hline $\begin{array}{l}\text { NN36/2008 - Rescue aid to } \\
\text { Roskilde Bank }\end{array}$ & $\begin{array}{l}\text { Decision not to raise objections } \\
\text { (IP/08/1222) }\end{array}$ & 31 July 2008 \\
\hline $\begin{array}{l}\text { NN39/2008 - Liquidation aid } \\
\text { Roskilde bank }\end{array}$ & $\begin{array}{l}\text { Decision not to raise objections } \\
\underline{\mathrm{IP} / 08 / 1633}\end{array}$ & 5 November 2008 \\
\hline $\begin{array}{l}\text { NN51/2008 - Guarantee scheme for banks in } \\
\text { Denmark }\end{array}$ & $\begin{array}{l}\text { Decision not to raise objections } \\
\text { IP/08/1483 }\end{array}$ & 10 October 2008 \\
\hline $\begin{array}{l}\text { N31a/2009-Amendment of the guarantee } \\
\text { scheme }\end{array}$ & $\begin{array}{l}\text { Decision not to raise objections } \\
\text { IP/09/206 }\end{array}$ & 17 August 2009 \\
\hline N20/2010 - Second prolongation & $\begin{array}{l}\text { Decision not to raise objections } \\
\text { MEX/10/0201 }\end{array}$ & 01 February 2010 \\
\hline N257/2010 - Extension & $\mathrm{IP} / 10 / 854$ & 28 June 2010 \\
\hline $\begin{array}{l}\text { N31a/2009 - Recapitalisation scheme (and } \\
\text { amendment of the guarantee scheme) }\end{array}$ & $\begin{array}{l}\text { Decision not to raise objections } \\
\text { IP/09/206 }\end{array}$ & 3 February 2009 \\
\hline NN46/2009 - Prolongation & MEX/09/0817 & 17 August 2009 \\
\hline N628/2009 - Second prolongation & $\underline{\mathrm{MEX} / 09 / 1217}$ & 17 December 2009 \\
\hline NN23/2009 - Rescue aid for Fionia Bank & $\begin{array}{l}\text { Decision not to raise objections } \\
\text { IP/09/819 }\end{array}$ & 20 May 2009 \\
\hline
\end{tabular}

\section{FINLAND}

\begin{tabular}{|c|c|c|}
\hline N567/2008 - Finnish guarantee scheme & $\begin{array}{l}\text { Decision not to raise objections } \\
\text { IP/08/1705 }\end{array}$ & 13 November 2008 \\
\hline $\begin{array}{l}\text { N44/2009 - Amendment to the guarantee } \\
\text { scheme }\end{array}$ & $\begin{array}{l}\text { Decision not to raise objections } \\
\text { IP/09/681 }\end{array}$ & 5 February 2009 \\
\hline N239/2009 - Prolongation and modification & MEX/09/0430 & 30 April 2009 \\
\hline $\begin{array}{l}\text { N674/2009 - Second prolongation and } \\
\text { modification }\end{array}$ & MEX/09/1217 & 17 December 2009 \\
\hline $\begin{array}{l}\text { NN2/2009 - Guarantee for Kaupthing Bank } \\
\text { Finland }\end{array}$ & $\begin{array}{l}\text { Decision not to raise objections } \\
\text { IP/09/82 }\end{array}$ & 21 January 2009 \\
\hline N329/2009 - Capital injection scheme & $\begin{array}{l}\text { Decision not to raise objections } \\
\text { IP/09/1303 }\end{array}$ & 11 September 2009 \\
\hline N110/2010 - Prolongation & MEX/10/0414 & 14 April 2010 \\
\hline
\end{tabular}

\section{FRANCE}

\begin{tabular}{|l|l|r|}
\hline $\begin{array}{l}\text { N548/2008 - Financial support measures to the } \\
\text { banking industry in France (Refinancing) }\end{array}$ & $\begin{array}{l}\text { Decision not to raise objections } \\
\mathbb{P} / 08 / 1609\end{array}$ & 30 October 2008 \\
\hline N251/2009 - Extension of the scheme & $\begin{array}{l}\text { Decision not to raise objections } \\
\mathbb{I P / 0 9 / 7 5 0}\end{array}$ & 12 May 2009 \\
\hline $\begin{array}{l}\text { N613/2008 - Financial support measures to the } \\
\text { banking industry in France (Recapitalisation) }\end{array}$ & $\begin{array}{l}\text { Decision not to raise objections } \\
\mathbb{I P / 0 8 / 1 9 0 0}\end{array}$ & 08 December 2008 \\
\hline N29/2009 - Amendment to the Decision & $\underline{\underline{I P} / 09 / 158}$ & 28 January 2009 \\
\hline N164/2009 - Amendment to the Decision & $\underline{\underline{P} / 09 / 461}$ & 23 March 2009 \\
\hline $\begin{array}{l}\text { N249/2009 - Capital injection for Caisse } \\
\text { d'Epargne and Banque Populaire }\end{array}$ & $\begin{array}{l}\text { Decision not to raise objections } \\
\mathbb{I P} / 09 / 722\end{array}$ & 8 May 2009 \\
\hline
\end{tabular}




\section{Germany}

\begin{tabular}{|c|c|c|}
\hline C9/2008 - Restructuring aid to Sachsen LB & $\begin{array}{l}\text { Conditional decision (after } \\
\text { formal investigation procedure } \\
\underline{\mathrm{IP} / 08 / 849}\end{array}$ & 4 June 2008 \\
\hline $\begin{array}{l}\text { C10/2008 - Restructuring aid } \\
\text { to IKB }\end{array}$ & $\begin{array}{l}\text { Conditional decision (after } \\
\text { formal investigation procedure) } \\
\text { IP/08/1557 }\end{array}$ & 21 October 2008 \\
\hline $\begin{array}{l}\text { NN44/2008 - Rescue aid to Hypo Real Estate } \\
\text { Holding }\end{array}$ & $\begin{array}{l}\text { Decision not to raise objections } \\
\underline{\mathrm{IP} / 08 / 1453}\end{array}$ & 2 October 2008 \\
\hline $\begin{array}{l}\text { N512/2008 - Aid scheme for financial institutions } \\
\text { in Germany (guarantees, recapitalisations \& } \\
\text { other) }\end{array}$ & $\begin{array}{l}\text { Decision not to raise objections } \\
\underline{\text { IP/08/1589 }}\end{array}$ & 27 October 2008 \\
\hline N625/2008 - Amendment to the Decision & & 12 December 2008 \\
\hline N330/2009 - Prolongation & EXME09/22.06 & 22 June 2009 \\
\hline N665/2009 - Second prolongation & MEX/09/1217 & 17 December 2009 \\
\hline N222/2010 - Extension & $\mathrm{IP} / 10 / 789$ & 23 June 2010 \\
\hline $\begin{array}{l}\text { N615/2008 - Guarantee and recapitalisation for } \\
\text { Bayern LB }\end{array}$ & $\begin{array}{l}\text { Decision not to raise objections } \\
\underline{\mathrm{IP} / 08 / 2034}\end{array}$ & 18 December 2008 \\
\hline N655/2008 - Guarantee for NordLB & $\begin{array}{l}\text { Decision not to raise objections } \\
\underline{\mathrm{IP} / 08 / 2056}\end{array}$ & 22 December 2008 \\
\hline N412/2009 - Prolongation & MEX/09/0910 & 10 September 2009 \\
\hline N639/2008 - Guarantee for IKB & $\begin{array}{l}\text { Decision not to raise objections } \\
\mathrm{IP} / 08 / 2055\end{array}$ & 22 December 2008 \\
\hline $\begin{array}{l}\text { N17/2009 - Guarantee for SdB - } \\
\text { Sicherungseinrichtungsgesellschaft deutscher } \\
\text { Banken mbH }\end{array}$ & $\begin{array}{l}\text { Decision not to raise objections } \\
\text { IP/09/114 }\end{array}$ & 22 January 2009 \\
\hline N244/2009 - Commerzbank capital injection & $\begin{array}{l}\text { Decision not to raise objections } \\
\text { IP/09/711 }\end{array}$ & 7 May 2009 \\
\hline C43/2008 - Aid for the restructuring of West LB & $\begin{array}{l}\text { Conditional decision (after } \\
\text { formal investigation procedure) } \\
\text { IP/09/741 }\end{array}$ & 12 May 2009 \\
\hline $\begin{array}{l}\text { N531/2009 - Temporary additional aid to West } \\
\text { LB }\end{array}$ & $\begin{array}{l}\text { Decision not to raise objections } \\
\mathrm{IP} / 09 / 1434\end{array}$ & 7 October 2009 \\
\hline N264/2009 - Recapitalisation of HSH Nordbank & $\begin{array}{l}\text { Decision not to raise objections } \\
\underline{\mathrm{IP} / 09 / 854}\end{array}$ & 29 May 2009 \\
\hline $\begin{array}{l}\text { C17/2009 - Recapitalisation and asset relief for } \\
\text { LBBW (Landesbank Baden Württemberg) }\end{array}$ & $\begin{array}{l}\text { Decision not to raise objections } \\
\underline{\mathrm{IP} / 09 / 1058}\end{array}$ & 30 June 2009 \\
\hline N314/2009 - German asset relief scheme & $\begin{array}{l}\text { Decision not to raise objections } \\
\text { IP/09/1216 }\end{array}$ & 31 July 2009 \\
\hline N400/2009 - Additional aid (guarantees) for IKB & $\begin{array}{l}\text { Decision not to raise objections } \\
\underline{\mathrm{IP} / 09 / 1235}\end{array}$ & 17 August 2009 \\
\hline $\begin{array}{l}\text { N } 456 / 2009 \text { - Scheme to facilitate the } \\
\text { refinancing of export credits }\end{array}$ & $\begin{array}{l}\text { Decision not to raise objections } \\
\text { IP/09/1319 }\end{array}$ & 15 September 2009 \\
\hline N 48/2010 - Prolongation & $\begin{array}{l}\text { Decision not to raise objections } \\
\text { MEX/10/0309 }\end{array}$ & 9 March 2010 \\
\hline $\begin{array}{l}\text { C17/2009 - Landesbank Baden Württemberg } \\
\text { "LBBW" - restructuring plan and impaired assets } \\
\text { relief measure }\end{array}$ & $\begin{array}{l}\text { Conditional decision (after } \\
\text { formal investigation procedure } \\
\text { IP/09/1927 }\end{array}$ & 15 December 2009 \\
\hline
\end{tabular}




\begin{tabular}{|l|l|r|}
\hline $\begin{array}{l}\text { N694/2009 - State guarantees for Hypo Real } \\
\text { Estate }\end{array}$ & $\begin{array}{l}\text { Decision not to raise objections } \\
\text { IP/09/1985 }\end{array}$ & 21 December 2009 \\
\hline $\begin{array}{l}\text { N555/2009 - Rescue aid for WestLB; in-depth } \\
\text { investigation into bad bank }\end{array}$ & $\begin{array}{l}\text { Decision not to raise objections } \\
\text { IP/09/1996 }\end{array}$ & 22 December 2009 \\
\hline $\begin{array}{l}\text { N161/2010 - Recapitalisation of Hypo Real } \\
\text { Estate }\end{array}$ & Decision not to raise objections & 19 May 2010 \\
\hline
\end{tabular}

\section{Greece}

\begin{tabular}{|l|l|r|}
\hline $\begin{array}{l}\text { N560/2008 - Aid scheme to the banking industry } \\
\text { in Greece (guarantees, recapitalisation \& other) }\end{array}$ & $\begin{array}{l}\text { Decision not to raise objections } \\
\text { IP/081742 }\end{array}$ & 19 November 2008 \\
\hline Prolongation and modification & $\underline{\mathrm{MEX} / 09 / 0918}$ & 18 September 2009 \\
\hline N690/2009 - Prolongation & $\underline{\text { MEX/10/0125 }}$ & 25 January 2010 \\
\hline N 163/2010 - Amendment & & 12 May 2010 \\
\hline
\end{tabular}

\section{HUNGARY}

\begin{tabular}{|c|c|c|}
\hline $\begin{array}{l}\text { N664/2008 - Financial support measures to } \\
\text { Hungarian financial industry in form of } \\
\text { recapitalisation and guarantee scheme }\end{array}$ & $\begin{array}{l}\text { Decision not to raise objections } \\
\underline{\text { IP/09/253 }}\end{array}$ & 12 February 2009 \\
\hline N355/2009 - Prolongation and modification & MEX09/0903 & 3 September 2009 \\
\hline N662/2009 - Second prolongation & MEX/09/1217 & 17 December 2009 \\
\hline $\begin{array}{l}\text { N224/2010 - Prolongation of Hungarian recap } \\
\text { scheme }\end{array}$ & $\underline{\mathrm{IP} / 10 / 789}$ & 23 June 2010 \\
\hline $\begin{array}{l}\text { N 358/2009 - Hungarian Mortgage Support } \\
\text { Scheme }\end{array}$ & $\begin{array}{l}\text { Decision not to raise objections } \\
\underline{\mathrm{IP} / 09 / 1123}\end{array}$ & 13 July 2009 \\
\hline N603/2009 - Prolongation & $\begin{array}{l}\text { Decision not to raise objections } \\
\text { MEX 09/1124 }\end{array}$ & 24 November 2009 \\
\hline $\begin{array}{l}\text { NN68/2009 - Hungarian liquidity support } \\
\text { scheme }\end{array}$ & $\begin{array}{l}\text { Decision not to raise objections } \\
\underline{\mathrm{P} / 10 / 19}\end{array}$ & 14 January 2010 \\
\hline N225/2010 - Extension & $\mathrm{IP} / 10 / 854$ & 28 June 2010 \\
\hline
\end{tabular}

\section{IRELAND}

\begin{tabular}{|c|c|c|}
\hline $\begin{array}{l}\text { NN48/2008 - Guarantee scheme } \\
\text { for banks in Ireland }\end{array}$ & $\begin{array}{l}\text { Decision not to raise objections } \\
\underline{I P / 08 / 1497}\end{array}$ & 13 October 2008 \\
\hline N9/2009 - Recapitalisation of Anglo Irish Bank & $\begin{array}{l}\text { Decision not to raise objections } \\
\mathrm{IP} / 09 / 50\end{array}$ & 14 January 2009 \\
\hline $\begin{array}{l}\text { N356/2009 - Recapitalisation of Anglo Irish } \\
\text { Bank }\end{array}$ & $\begin{array}{l}\text { Decision not to raise objections } \\
\text { IP/09/1045 }\end{array}$ & 26 June 2009 \\
\hline $\begin{array}{l}\text { N61/2009 - Change of ownership of Anglo Irish } \\
\text { Bank }\end{array}$ & $\begin{array}{l}\text { Decision not to raise objections } \\
\text { IP/09/271 }\end{array}$ & 17 February 2009 \\
\hline N149/2009 - Recapitalisation of Bank of Ireland & $\begin{array}{l}\text { Decision not to raise objections } \\
\text { IP/09/483 }\end{array}$ & 26 March 2009 \\
\hline N241/2009 - Recapitalisation of Allied Irish Bank & $\begin{array}{l}\text { Decision not to raise objections } \\
\mathrm{IP} / 09 / 744\end{array}$ & 12 May 2009 \\
\hline $\begin{array}{l}\text { N349/2009 - revised Irish guarantee scheme for } \\
\text { financial institutions }\end{array}$ & $\begin{array}{l}\text { Decision not to raise objections } \\
\text { IP/09/1787 }\end{array}$ & 20 November 2009 \\
\hline Prolongation & $\begin{array}{l}\text { Decision not to raise objections } \\
\text { MEX/10/0531 }\end{array}$ & 31 May 2010 \\
\hline N254/2010 - Extension & $\mathrm{IP} / 10 / 854$ & 28 June 2010 \\
\hline
\end{tabular}




\begin{tabular}{|l|l|r|}
\hline $\begin{array}{l}\text { N725/2009 - Irish impaired asset relief scheme } \\
\text { (National Asset Management Agency (NAMA)) }\end{array}$ & $\begin{array}{l}\text { Decision not to raise objections } \\
\underline{\mathrm{IP} / 10 / 198}\end{array}$ & 26 February 2010 \\
\hline $\begin{array}{l}\text { NN11/2010 - Temporary approval of Rescue } \\
\text { measure in favour of INBS }\end{array}$ & $\begin{array}{l}\text { Decision not to raise objections } \\
\underline{\mathrm{IP} / 10 / 400}\end{array}$ & 30 March 2010 \\
\hline $\begin{array}{l}\text { NN12/2010 and C11/2010 - Temporary } \\
\text { approval of Second recapitalisation of Anglo } \\
\text { Irish Bank and restructuring of Anglo Irish Bank }\end{array}$ & $\begin{array}{l}\text { Decision not to raise objections } \\
\text { on recapitalisation, and opening } \\
\text { of proceedings on restructuring } \\
\underline{\mathrm{IP} / 10 / 400}\end{array}$ & 31 March 2010 \\
\hline $\begin{array}{l}\text { N160/2010 - Temporary approval of } \\
\text { recapitalisation of EBS }\end{array}$ & $\begin{array}{l}\text { Decision not to raise objections } \\
\underline{\mathrm{IP} / 10 / 658}\end{array}$ & 2 June 2010 \\
\hline
\end{tabular}

\section{ITALY}

\begin{tabular}{|l|l|r|}
\hline $\begin{array}{l}\text { N520a/2008 - Guarantee scheme for Italian } \\
\text { banks }\end{array}$ & $\begin{array}{l}\text { Decision not to raise objections } \\
\mathrm{IP} / 08 / 1706\end{array}$ & 14 November 2008 \\
\hline N328/2009 - Prolongation & $\underline{\mathrm{IP} / 09 / 929}$ & 16 June 2009 \\
\hline N648/2008 - Recapitalisation scheme & $\begin{array}{l}\text { Decision not to raise objections } \\
\mathrm{IP} / 08 / 2059\end{array}$ & 23 December 2008 \\
\hline N97/2009 - Amendment & & 20 February 2009 \\
\hline N 466/2009 - Prolongation & $\underline{M E X / 09 / 1006}$ & 6 October 2009 \\
\hline
\end{tabular}

\section{LATVIA}

\begin{tabular}{|l|l|r|}
\hline $\begin{array}{l}\text { NN68/2008 - Public support measures to Parex } \\
\text { Banka }\end{array}$ & $\begin{array}{l}\text { Decision not to raise objections } \\
\underline{I P / 08 / 1766}\end{array}$ & 24 November 2008 \\
\hline NN3/2009 - Amendment to the Decision & & 11 February 2009 \\
\hline N189/2009 - Amendment to the Decision & $\underline{I P / 09 / 732}$ & 11 May 2009 \\
\hline N638/2008 - Guarantee scheme for banks & $\begin{array}{l}\text { Decision not to raise objections } \\
\mathrm{IP} / 08 / 2054\end{array}$ & 22 December 2008 \\
\hline N326/2009 - Prolongation & $\underline{\mathrm{MEX} / 09 / 0630}$ & 30 June 2009 \\
\hline N664/2009 - Second prolongation & $\underline{\mathrm{MEX} / 09 / 1217}$ & 17 December 2009 \\
\hline N223/2010 - Extension & $\underline{\mathrm{IP} / 10 / 839}$ & 24 June 2010 \\
\hline $\begin{array}{l}\text { NN60/2009 - Capital injection for Mortgage } \\
\text { Bank of Latvia }\end{array}$ & $\begin{array}{l}\text { Decision not to raise objections } \\
\underline{\mathrm{IP} / 09 / 1742}\end{array}$ & 19 November 2009 \\
\hline
\end{tabular}

\section{LUXEMBOURG}

\begin{tabular}{|l|l|r|}
\hline $\begin{array}{l}\text { N344/2009\&N380/2009 - Restructuring aid for } \\
\text { Kaupthing Bank Luxembourg }\end{array}$ & $\begin{array}{l}\text { Decision not to raise objections } \\
\text { IP/09/1107 }\end{array}$ & 9 July 2009 \\
\hline
\end{tabular}

\section{NetherLands}

\begin{tabular}{|l|l|r|}
\hline $\begin{array}{l}\text { N524/2008 - Guarantee scheme for Dutch } \\
\text { financial institutions }\end{array}$ & $\begin{array}{l}\text { Decision not to raise objections } \\
\text { IP/08/1610 }\end{array}$ & 30 October 2008 \\
\hline N379/2009 - Prolongation and modification & $\underline{\mathrm{MEX} / 09 / 0707}$ & 7 July 2009 \\
\hline N669/2009 - Second prolongation & $\underline{\mathrm{MEX} / 09 / 1217}$ & 17 December 2009 \\
\hline N528/2008 - Measure in favour of ING & $\begin{array}{l}\text { Decision not to raise objections } \\
\text { IP/08/1699 }\end{array}$ & 13 November 2008 \\
\hline
\end{tabular}




\begin{tabular}{|l|l|r|}
\hline N569/2008 - Measure in favour of Aegon & $\begin{array}{l}\text { Decision not to raise objections } \\
\text { IP/08/1822 }\end{array}$ & 27 November 2008 \\
\hline $\begin{array}{l}\text { N611/2008 - SNS REAAL/New capital injection } \\
\text { by Dutch authorities }\end{array}$ & $\begin{array}{l}\text { Decision not to raise objections } \\
\text { IP/08/1951 }\end{array}$ & 10 December 2008 \\
\hline C10/2009 - ING Illiquid asset facility & $\begin{array}{l}\text { Decision not to raise objections } \\
\text { IP/09/514 }\end{array}$ & 31 March 2009 \\
\hline $\begin{array}{l}\text { C10/2009 - ING restructuring plan and illiquid } \\
\text { asset back-up facility }\end{array}$ & $\begin{array}{l}\text { Final conditional decision after } \\
\text { formal investigation procedure } \\
\text { IP/09/1729 }\end{array}$ & 18 November 2009 \\
\hline $\begin{array}{l}\text { N371/2009 - Approval of recapitalisation of } \\
\text { SNS REAAL }\end{array}$ & $\begin{array}{l}\text { Decision not to raise objections } \\
\text { IP/10/82 }\end{array}$ & 28 January 2010 \\
\hline $\begin{array}{l}\text { N } 19 / 2010, \text { NN 2/2010, C11/2009 - Temporary } \\
\text { approval of additional recapitalisation package } \\
\text { in favour of ABN AMRO and Fortis Bank } \\
\text { Nederland }\end{array}$ & $\begin{array}{l}\text { Decision not to raise objections } \\
\text { IP/10/138 }\end{array}$ & 4 February 2010 \\
\hline
\end{tabular}

\section{PolAND}

\begin{tabular}{|l|l|r|}
\hline $\begin{array}{l}\text { N208/2009 - Polish support scheme for financial } \\
\text { institutions (guarantee and liquidity support) }\end{array}$ & $\begin{array}{l}\text { Decision not to raise objections } \\
\text { IP/09/1360 }\end{array}$ & 25 September 2009 \\
\hline Prolongation & MEX/10/0209 & 9 February 2010 \\
\hline $\begin{array}{l}\text { N302/2009 - Polish bank recapitalisation } \\
\text { scheme }\end{array}$ & $\begin{array}{l}\text { Decision not to raise objections } \\
\text { IP/09/1979 }\end{array}$ & 21 December 2009 \\
\hline
\end{tabular}

\section{Portugal}

\begin{tabular}{|l|l|r|}
\hline $\begin{array}{l}\text { NN60/2008 - Guarantee scheme for credit } \\
\text { institutions in Portugal }\end{array}$ & $\begin{array}{l}\text { Decision not to raise objections } \\
\text { IP/08/1601 }\end{array}$ & 29 October 2008 \\
\hline N51/2010 - Prolongation & MEX/10/0222 & 22 February 2010 \\
\hline & & 13 March 2009 \\
\hline $\begin{array}{l}\text { NN71/2008 - State guarantee for Banco Privado } \\
\text { Português }\end{array}$ & $\begin{array}{l}\text { Decision not to raise objections } \\
\text { IP/09/400 }\end{array}$ & 20 May 2009 \\
\hline N556/2008 - Bank recapitalisation scheme & $\begin{array}{l}\text { Decision not to raise objections } \\
\text { IP/09/818 }\end{array}$ & 17 March 2010 \\
\hline N 80/2010 - Prolongation & \begin{tabular}{l} 
MEX/10/0317 \\
\hline
\end{tabular} & \\
\hline
\end{tabular}

\section{SLOVAKIA}

\begin{tabular}{|l|l|r|}
\hline $\begin{array}{l}\text { N392/2009 - Slovak bank support scheme } \\
\text { (guarantees and recapitalisations) }\end{array}$ & $\begin{array}{l}\text { Decision not to raise objections } \\
\underline{I P / 09 / 1889}\end{array}$ & 8 December 2009 \\
\hline
\end{tabular}

\section{Slovenia}

\begin{tabular}{|l|l|r|}
\hline $\begin{array}{l}\text { N531/2008 - Guarantee scheme for credit } \\
\text { institutions in Slovenia }\end{array}$ & $\begin{array}{l}\text { Decision not to raise objections } \\
\text { IP/08/1964 }\end{array}$ & 12 December 2008 \\
\hline N331/2009 - Prolongation & $\underline{\underline{E X M E 09 / 22.06}}$ & 22 June 2009 \\
\hline N651/2009 - Second prolongation & $\underline{\text { MEX/09/1217 }}$ & 17 December 2009 \\
\hline $\begin{array}{l}\text { N637/2008 - Liquidity scheme for financial } \\
\text { sector }\end{array}$ & $\begin{array}{l}\text { Decision not to raise objections } \\
\text { IP/09/452 }\end{array}$ & 20 March 2009 \\
\hline N510/2009 - Prolongation & $\underline{\text { MEX09/1910 }}$ & 19 October 2009 \\
\hline N113/2010 - Second Prolongation & $\underline{M E X 10 / 0415}$ & 15 April 2010 \\
\hline
\end{tabular}




\begin{tabular}{|c|c|c|}
\hline $\begin{array}{l}\text { NN54a/2008 - Fund for the Acquisition of } \\
\text { Financial Assets in Spain }\end{array}$ & $\begin{array}{l}\text { Decision not to raise objections } \\
\mathrm{IP} / 08 / 1630\end{array}$ & 4 November 2008 \\
\hline Modification & Decision not to raise objections & 8 April 2009 \\
\hline N337/2009 - Prolongation & MEX09/0807 & 7 August 2009 \\
\hline $\begin{array}{l}\text { NN54b/2008 - Spanish guarantee scheme for } \\
\text { credit institutions }\end{array}$ & $\begin{array}{l}\text { Decision not to raise objections } \\
\mathrm{IP} / 08 / 2049\end{array}$ & 22 December 2008 \\
\hline Prolongation & MEX09/0625 & 25 June 2009 \\
\hline N588/2009 - Second prolongation & $\overline{M E X / 09 / 1201}$ & 1 December 2009 \\
\hline $\begin{array}{l}\text { N28/2010 - Spanish recapitalisation scheme for } \\
\text { credit institutions (Fondo de Reestructuración } \\
\text { Ordenada Bancaria" (FROB)) }\end{array}$ & $\begin{array}{l}\text { Decision not to raise objections } \\
\underline{\mathrm{IP} / 10 / 70}\end{array}$ & 28 January 2010 \\
\hline
\end{tabular}

\section{SWEDEN}

\begin{tabular}{|c|c|c|}
\hline $\begin{array}{l}\text { N533/2008 - Support measures for the banking } \\
\text { industry in Sweden (guarantees) }\end{array}$ & $\begin{array}{l}\text { Decision not to raise objections } \\
\mathrm{IP} / 08 / 1600\end{array}$ & 29 October 2008 \\
\hline N26/2009 - Amendment to the decision & $\mathrm{IP} / 09 / 186$ & 28 January 2009 \\
\hline N154/2009 - Amendment and prolongation & $\mathrm{IP} / 09 / 652$ & 28 April 2009 \\
\hline N544/2009 - Prolongation & MEX/09/1026 & 26 October 2009 \\
\hline N 127/2010 - Second Prolongation & MEX/10/0422 & 22 April 2010 \\
\hline $\begin{array}{l}\text { N 207/2010 - Extension of Swedish guarantee } \\
\text { scheme }\end{array}$ & MEX/10/0615 & 15 June 2010 \\
\hline $\begin{array}{l}\text { NN64/2008 - Emergency rescue measures } \\
\text { regarding Carnegie Investment Bank }\end{array}$ & $\begin{array}{l}\text { Decision not to raise objections } \\
\text { IP/08/1977 }\end{array}$ & 15 December 2008 \\
\hline N69/2009 - Recapitalisation scheme & $\begin{array}{l}\text { Decision not to raise objections } \\
\text { IP/09/241 }\end{array}$ & 11 February 2009 \\
\hline N436/2009 - Prolongation & MEX09/0805 & 5 August 2009 \\
\hline $\begin{array}{l}\text { NN 18/2010 - Clearance of restructuring aid for } \\
\text { Carnegie Investment Bank }\end{array}$ & $\begin{array}{l}\text { Decision not to raise objections } \\
\mathrm{IP} / 10 / 558\end{array}$ & 12 May 2010 \\
\hline
\end{tabular}

\section{UNITED KINGDOM}

\begin{tabular}{|c|c|c|}
\hline $\begin{array}{l}\text { NN41/2008 - Rescue aid to Bradford and } \\
\text { Bingley }\end{array}$ & $\begin{array}{l}\text { Decision not to raise objections } \\
\underline{\mathrm{IP} / 08 / 1437}\end{array}$ & $1^{\text {st }}$ October 2008 \\
\hline $\begin{array}{l}\text { N507/2008 - Aid scheme to the banking industry } \\
\text { in the UK (guarantees, recapitalisation \& other) }\end{array}$ & $\begin{array}{l}\text { Decision not to raise objections } \\
\mathrm{IP} / 08 / 1496\end{array}$ & 13 October 2008 \\
\hline N650/2008 - Amendment to the Decision & & 23 December 2008 \\
\hline N193/2009 - Prolongation & $\mathrm{IP} / 09 / 586$ & 15 April 2009 \\
\hline N537/2009 - Prolongation & $\mathrm{MEX} / 10 / 13$ & 13 October 2009 \\
\hline N677/2009 - Prolongation & MEX/09/1217 & 17 December 2009 \\
\hline N111/2009 - Working capital guarantee scheme & $\begin{array}{l}\text { Decision not to raise objections } \\
\mathrm{IP} / 09 / 471\end{array}$ & 24 March 2009 \\
\hline UK Asset backed Secl & $\begin{array}{l}\text { Decision not to raise objections } \\
\underline{\mathrm{P} / 09 / 613}\end{array}$ & 2009 \\
\hline Prolongation & MEX/09/1027 & 27 October 2009 \\
\hline $\begin{array}{l}\text { C14/2008 - Restructuring package for Northern } \\
\text { Rock }\end{array}$ & $\begin{array}{l}\text { Final conditional decision after } \\
\text { formal investigation procedure } \\
\underline{\mathrm{IP} / 09 / 1600}\end{array}$ & 28 October 2009 \\
\hline $\begin{array}{l}\text { N428/2009 - Restructuring plan of Lloyds } \\
\text { Banking Group }\end{array}$ & $\begin{array}{l}\text { Decision not to raise objections } \\
\underline{\mathrm{IP} / 09 / 1728}\end{array}$ & 18 November 2009 \\
\hline
\end{tabular}




\begin{tabular}{|l|l|c|}
\hline & & \\
\hline $\begin{array}{l}\text { N422/2009 and N621/2009 - Royal Bank of } \\
\text { Scotland, impaired asset relief measure and } \\
\text { restructuring plan }\end{array}$ & $\begin{array}{l}\text { Decision not to raise objections } \\
\underline{\mathrm{IP} / 09 / 1915}\end{array}$ & 14 December 2009 \\
\hline $\begin{array}{l}\text { N194/2009 - Liquidation aid to Bradford \& } \\
\text { Bingley }\end{array}$ & $\begin{array}{l}\text { Decision not to raise objections } \\
\underline{\mathrm{IP} / 10 / 47}\end{array}$ & 25 January 2010 \\
\hline $\begin{array}{l}\text { NN19/2009 - Restructuring of Dunfermline } \\
\text { Building Society }\end{array}$ & $\begin{array}{l}\text { Decision not to raise objections } \\
\underline{\mathrm{IP} / 10 / 48}\end{array}$ & 25 January 2010 \\
\hline
\end{tabular}

\section{Cases currently under formal investigation procedure (in-depth investigation under the EC Treaty's rules on state aid)}

\begin{tabular}{|c|c|c|c|}
\hline Country & Type of measure / Beneficiary & $\begin{array}{l}\text { Date of decision } \\
\text { regarding the } \\
\text { opening of formal } \\
\text { investigation }\end{array}$ & \\
\hline Germany & $\begin{array}{l}\text { C15/2009 - Aid package for Hypo Real } \\
\text { Estate (restructuring) } \\
\text { Extension and temporary approval of } \\
\text { capital injections }\end{array}$ & $\begin{array}{l}7 \text { May } 2009 \\
\underline{\mathrm{IP} / 09 / 712} \\
13 \text { November } \\
2009 \\
\underline{\mathrm{IP} / 09 / 1708} \\
\end{array}$ & $\begin{array}{l}\text { Case under } \\
\text { assessment }\end{array}$ \\
\hline Germany, Austria & $\begin{array}{l}\text { C16/2009 - Aid package for Bayern LB } \\
\text { and its Austrian subsidiary Hypo Group } \\
\text { Alpe Adria } \\
\text { Extension } \\
\text { C } 16 / 2009 \text { - Extension of temporary } \\
\text { approval of restructuring aid for Hypo } \\
\text { Group Alpe Adria }\end{array}$ & $\begin{array}{l}\text { 12 May } 2009 \\
\underline{\mathrm{IP} / 09 / 742} \\
\\
23 \text { December } \\
2009 \\
\underline{\mathrm{IP} / 09 / 1998} \\
22 \text { June } 2010 \\
\underline{\mathrm{IP} / 10 / 774}\end{array}$ & $\begin{array}{l}\text { Case under } \\
\text { assessment }\end{array}$ \\
\hline Germany & $\begin{array}{l}\text { C29/2009 - Aid package for HSH } \\
\text { Nordbank AG }\end{array}$ & $\begin{array}{l}22 \text { October } 2009 \\
\underline{\mathrm{IP} / 09 / 1577}\end{array}$ & $\begin{array}{l}\text { Case under } \\
\text { assessment }\end{array}$ \\
\hline Germany & $\begin{array}{l}\text { C32/2009 - Support measures for German } \\
\text { savings bank Sparkasse KölnBonn }\end{array}$ & $\begin{array}{l}5 \text { November } 2009 \\
\underline{\mathrm{IP} / 09 / 1670}\end{array}$ & $\begin{array}{l}\text { Case under } \\
\text { assessment }\end{array}$ \\
\hline Germany & $\begin{array}{l}\text { C43/2009 - WestLB: in-depth } \\
\text { investigation into bad bank } \\
\text { C43/2009 - Prolongation of temporary } \\
\text { approval of aid to WestLB }\end{array}$ & $\begin{array}{l}22 \text { December } \\
2009 \\
\underline{\mathrm{IP} / 09 / 1996} \\
\text { 22 June } 2010 \\
\underline{\text { IP/10/774 }}\end{array}$ & $\begin{array}{l}\text { Case under } \\
\text { assessment }\end{array}$ \\
\hline Ireland & $\begin{array}{l}\text { C11/2010 - Temporary approval of } \\
\text { Second recapitalisation of Anglo Irish } \\
\text { Bank and restructuring of Anglo Irish } \\
\text { Bank }\end{array}$ & $\begin{array}{l}31 \text { March } 2010 \\
\underline{I P / 10 / 400}\end{array}$ & $\begin{array}{l}\text { Case under } \\
\text { assessment }\end{array}$ \\
\hline
\end{tabular}




\begin{tabular}{|c|c|c|c|}
\hline & & & \\
\hline Latvia & $\begin{array}{l}\text { C26/2009 - Aid package for JSC Parex } \\
\text { Banka }\end{array}$ & $\begin{array}{l}29 \text { July } 2009 \\
\text { IP/09/1203 }\end{array}$ & $\begin{array}{l}\text { Case under } \\
\text { assessment }\end{array}$ \\
\hline Netherlands & $\begin{array}{l}\text { C11/B/2008 - State measures in favour of } \\
\text { Fortis Bank Nederland (FBN) and the } \\
\text { activities of ABN Amro } \\
\text { Extension }\end{array}$ & $\begin{array}{l}8 \text { April } 2009 \\
\text { IP/09/565 } \\
\\
\text { 4 February } 2010 \\
\text { IP/10/138 }\end{array}$ & $\begin{array}{l}\text { Case under } \\
\text { assessment }\end{array}$ \\
\hline Portugal & $\begin{array}{l}\text { C33/2009 - State guarantee for Banco } \\
\text { Privado Português }\end{array}$ & $\begin{array}{l}10 \text { November } \\
2009 \\
\text { IP/09/1691 }\end{array}$ & $\begin{array}{l}\text { Case under } \\
\text { assessment }\end{array}$ \\
\hline
\end{tabular}


Real economy cases falling under the Temporary Framework - situation as of 29 June 2010

Decisions adopted by the Commission in 2008-2010

\section{AUSTRIA}

\begin{tabular}{|l|l|r|}
\hline \multicolumn{1}{|c|}{ Type of measure / Beneficiary } & \multicolumn{1}{|c|}{ Type of Decision } & Date of adoption \\
\hline $\begin{array}{l}\text { N 47/a/2009- Temporary scheme (aid up to } \\
€ 500000)\end{array}$ & $\begin{array}{l}\text { Decision not to raise objections } \\
\text { IP/09/454 }\end{array}$ & 20 March 2009 \\
N 317/2009 - Amendment & $\underline{\text { IP/09/972 }}$ & 18 June 2009 \\
\hline $\begin{array}{l}\text { N 47/d/2009- Temporary scheme (risk } \\
\text { capital) }\end{array}$ & $\begin{array}{l}\text { Decision not to raise objections } \\
\text { IP/09/484 }\end{array}$ & 25 March 2009 \\
\hline $\begin{array}{l}\text { N 434/2009 - Temporary scheme (export- } \\
\text { credit insurance) }\end{array}$ & $\begin{array}{l}\text { Decision not to raise objections } \\
\text { IP/09/1955 }\end{array}$ & 17 December 2009 \\
\hline $\begin{array}{l}\text { N 118/2010 - Temporary scheme (aid up to } \\
€ 15000 \text { for the agricultural sector) }\end{array}$ & $\begin{array}{l}\text { Decision not to raise objections } \\
\text { IP/10/453 }\end{array}$ & 19 April 2010 \\
\hline
\end{tabular}

\section{BELGIUM}

\begin{tabular}{|l|l|c|}
\hline $\begin{array}{l}\text { N 117/2009- Temporary scheme } \\
\text { (subsidised guarantees) }\end{array}$ & $\begin{array}{l}\text { Decision not to raise objections } \\
\text { IP/09/447 }\end{array}$ & 20 March 2009 \\
\hline $\begin{array}{l}\text { N 532/2009 - Temporary scheme (export- } \\
\text { credit-insurance) }\end{array}$ & $\begin{array}{l}\text { Decision not to raise objections } \\
\text { IP/09/1680 }\end{array}$ & 6 November 2009 \\
\hline $\begin{array}{l}\text { N 34/2010 - Temporary scheme (aid up to } \\
€ 15000 \text { for the agricultural sector) }\end{array}$ & $\begin{array}{l}\text { Decision not to raise objections } \\
\text { IP/10/160 }\end{array}$ & 11 February 2010 \\
\hline
\end{tabular}

\section{BULGARIA}

\begin{tabular}{|l|l|c|}
\hline $\begin{array}{l}\mathrm{N} 108 / 2010 \text { - Temporary scheme (aid up } \\
000 \text { for the agricultural sector) }\end{array}$ & $\begin{array}{l}\text { Decision not to raise objections } \\
\underline{\mathrm{IP} / 10 / 454}\end{array}$ & 19 April 2010 \\
\hline
\end{tabular}

\section{Czech Republic}

\begin{tabular}{|l|l|c|}
\hline $\begin{array}{l}\text { N 237/2009 - Temporary scheme } \\
\text { (subsidised interest rates) }\end{array}$ & $\begin{array}{l}\text { Decision not to raise objections } \\
\underline{\mathrm{IP} / 09 / 699}\end{array}$ & 6 May 2009 \\
\hline $\begin{array}{l}\mathrm{N} 236 / 2009-\text { Temporary scheme (aid up } \\
\text { to } € 500000)\end{array}$ & $\begin{array}{l}\text { Decision not to raise objections } \\
\underline{\mathrm{IP} / 09 / 719}\end{array}$ & 7 May 2009 \\
\hline
\end{tabular}

\section{DENMARK}

\begin{tabular}{|l|l|r|}
\hline $\begin{array}{l}\text { N 198/2009 - Temporary scheme (export- } \\
\text { credit insurance) }\end{array}$ & $\begin{array}{l}\text { Decision not to raise objections } \\
\underline{\mathrm{IP} / 09 / 706}\end{array}$ & 6 May 2009 \\
N 554/2009 (amendment) & $\underline{\mathrm{IP} / 09 / 1630}$ & 29 October 2009 \\
\hline
\end{tabular}

\section{ESTONIA}

N 387/2009 - Temporary scheme (aid up to $€ 500000)$ 


\section{FINLAND}

\begin{tabular}{|c|c|c|}
\hline $\begin{array}{l}\text { N 224/2009 - Temporary scheme (aid up } \\
\text { to } € 500000 \text { ) }\end{array}$ & $\begin{array}{l}\text { Decision not to raise objections } \\
\text { IP/09/869 }\end{array}$ & 3 June 2009 \\
\hline $\begin{array}{l}\text { N } 82 \mathrm{~b} / 2009 \text { - Temporary scheme } \\
\text { (guarantees) }\end{array}$ & $\begin{array}{l}\text { Decision not to raise objections } \\
\text { IP/09/919 }\end{array}$ & 9 June 2009 \\
\hline $\begin{array}{l}\text { N 258/2009 - Temporary scheme (export- } \\
\text { credit insurance) }\end{array}$ & $\begin{array}{l}\text { Decision not to raise objections } \\
\text { IP/09/979 }\end{array}$ & 22 June 2009 \\
\hline $\begin{array}{l}\mathrm{N} 141 / 2010 \text { - Temporary scheme (aid up } \\
\text { to } € 15000 \text { for the agricultural sector) }\end{array}$ & $\begin{array}{l}\text { Decision not to raise objections } \\
I \mathrm{P} / 10 / 604\end{array}$ & 20 May 2010 \\
\hline
\end{tabular}

\section{FRANCE}

\begin{tabular}{|c|c|c|}
\hline $\begin{array}{l}\text { N 7/2009-Temporary scheme (aid up to } \\
€ 500000 \text { ) }\end{array}$ & $\begin{array}{l}\text { Decision not to raise objections } \\
\mathbb{I P} / 09 / 72\end{array}$ & 19 January 2009 \\
\hline $\begin{array}{l}\text { N 15/2009 - Temporary scheme (reduced } \\
\text { interest rates) }\end{array}$ & $\begin{array}{l}\text { Decision not to raise objections } \\
\text { IP/09/216 }\end{array}$ & 4 February 2009 \\
\hline $\begin{array}{l}\mathrm{N} 11 / 2009 \text { - Temporary scheme (reduced } \\
\text { interest rates - to producers of green } \\
\text { products) }\end{array}$ & $\begin{array}{l}\text { Decision not to raise objections } \\
\text { IP/09/205 }\end{array}$ & 3 February 2009 \\
\hline $\begin{array}{l}\text { N 23/2009 - Temporary scheme } \\
\text { (subsidised guarantees) }\end{array}$ & $\begin{array}{l}\text { Decision not to raise objections } \\
\text { IP/09/332 }\end{array}$ & 27 February 2009 \\
\hline $\begin{array}{l}\text { N 119/2009 - modification of French risk } \\
\text { capital scheme }\end{array}$ & $\begin{array}{l}\text { Decision not to raise objections } \\
\underline{\mathrm{IP} / 09 / 406}\end{array}$ & 16 March 2009 \\
\hline $\begin{array}{l}\text { N } 36 / 2009 \text { - Temporary scheme (risk } \\
\text { capital) }\end{array}$ & $\begin{array}{l}\text { Decision not to raise objections } \\
\text { IP/09/1094 }\end{array}$ & 30 June 2009 \\
\hline $\begin{array}{l}\text { N } 449 / 2009 \text { - Temporary scheme (export- } \\
\text { credit insurance) }\end{array}$ & $\begin{array}{l}\text { Decision not to raise objections } \\
\text { IP/09/1422 }\end{array}$ & 5 October 2009 \\
\hline $\begin{array}{l}\mathrm{N} 609 / 2009 \text { - Temporary scheme (aid up } \\
\text { to } € 15000 \text { for the agricultural sector) }\end{array}$ & $\begin{array}{l}\text { Decision not to raise objections } \\
\underline{\mathrm{P} / 09 / 1866}\end{array}$ & 2 December 2009 \\
\hline
\end{tabular}

\section{Germany}

\begin{tabular}{|c|c|c|}
\hline $\begin{array}{l}\text { N } 661 / 2008 \text { - KfW run special program } \\
2009 \text { (interest subsidies) }\end{array}$ & $\begin{array}{l}\text { Decision not to raise objections } \\
(\underline{\mathrm{IP} / 08 / 2063)}\end{array}$ & 30 December 2008 \\
\hline $\begin{array}{l}\text { N 668/2008 - Temporary scheme (limited } \\
\text { amount of compatible aid) }\end{array}$ & $\begin{array}{l}\text { Decision not to raise objections } \\
\text { IP/08/2063 }\end{array}$ & 30 December 2008 \\
\hline N 299/2009 - Amendment & $\underline{\mathrm{IP} / 09 / 877}$ & \\
\hline - Amendment & & \\
\hline & & 17 July 2009 \\
\hline $\begin{array}{l}\text { N 39/2009 - Temporary adaptation of } \\
\text { risk-capital schemes }\end{array}$ & $\begin{array}{l}\text { Decision not to raise objections } \\
\mathrm{IP} / 09 / 214\end{array}$ & 3 February 2009 \\
\hline $\begin{array}{l}\text { N 27/2009 - Temporary scheme } \\
\text { (guarantees) }\end{array}$ & $\begin{array}{l}\text { Decision not to raise objections } \\
\text { IP/09/331 }\end{array}$ & 27 February 2009 \\
\hline $\begin{array}{l}\text { N 38/2009 - Temporary scheme (reduced } \\
\text { interest rates) }\end{array}$ & $\begin{array}{l}\text { Decision not to raise objections } \\
\text { IP/09/296 }\end{array}$ & 19 February 2009 \\
\hline $\begin{array}{l}\text { N } 426 / 2009 \text { - Temporary Scheme (green } \\
\text { products) }\end{array}$ & $\begin{array}{l}\text { Decision not to raise objections } \\
\text { IP/09/1223 }\end{array}$ & 4 August 2009 \\
\hline $\begin{array}{l}\text { N 384/2009 - Temporary Scheme (export } \\
\text { credit insurance) }\end{array}$ & $\begin{array}{l}\text { Decision not to raise objections } \\
\text { IP/09/1222 }\end{array}$ & 5 August 2009 \\
\hline mendment & & 31 May 2010 \\
\hline
\end{tabular}




\section{GREeCE}

\begin{tabular}{|l|l|r|}
\hline $\begin{array}{l}\text { N 308/2009 - Temporary scheme } \\
\text { (guarantees) }\end{array}$ & $\begin{array}{l}\text { Decision not to raise objections } \\
\text { IP/09/867 }\end{array}$ & 3 June 2009 \\
\hline $\begin{array}{l}\text { N 309/2009 - Temporary scheme } \\
\text { (subsidised interest rates) }\end{array}$ & $\begin{array}{l}\text { Decision not to raise objections } \\
\text { IP/09/868 }\end{array}$ & 3 June 2009 \\
\hline $\begin{array}{l}\text { N 304/2009 - Temporary scheme (aid up } \\
\text { to } € 500000)\end{array}$ & $\begin{array}{l}\text { Decision not to raise objections } \\
\underline{\text { IP/09/1143 }}\end{array}$ & 15 July 2009 \\
& & \\
\hline
\end{tabular}

\section{HUNGARY}

\begin{tabular}{|c|c|c|}
\hline $\begin{array}{l}\text { N 77/2009 - Temporary scheme (aid up to } \\
€ 500 \text { 000) }\end{array}$ & $\begin{array}{l}\text { Decision not to raise objections } \\
\underline{\mathbb{P} / 09 / 325}\end{array}$ & 24 February 2009 \\
\hline $\begin{array}{l}\mathrm{N} 78 / 2009 \text { - Temporary scheme } \\
\text { (subsidised interest rates) }\end{array}$ & $\begin{array}{l}\text { Decision not to raise objections } \\
\mathrm{IP} / 09 / 325\end{array}$ & 24 February 2009 \\
\hline $\begin{array}{l}\text { N 114/2009- Temporary scheme } \\
\text { (guarantees) }\end{array}$ & $\begin{array}{l}\text { Decision not to raise objections } \\
\mathrm{IP} / 09 / 387\end{array}$ & 10 March 2009 \\
\hline $\begin{array}{l}\text { N 203/2009 - Temporary scheme } \\
\text { (guarantees) }\end{array}$ & $\begin{array}{l}\text { Decision not to raise objections } \\
\text { IP/09/647 }\end{array}$ & 24 April 2009 \\
\hline $\begin{array}{l}\text { N 341/2009 - Temporary scheme } \\
\text { (guarantee methodology) }\end{array}$ & Decision not to raise objections & 1 July 2009 \\
\hline N 56/2010 - Amendment & & 6 May 2010 \\
\hline $\begin{array}{l}\text { N } 679 / 2009 \text { - Temporary scheme (aid up } \\
\text { to } € 15000 \text { for the agricultural sector) }\end{array}$ & $\begin{array}{l}\text { Decision not to raise objections } \\
\mathrm{IP} / 10 / 121\end{array}$ & 5 January 2010 \\
\hline
\end{tabular}

\section{IRELAND}

\begin{tabular}{|l|l|r|}
\hline $\begin{array}{l}\mathrm{N} 186 / 2009-\text { Temporary scheme (aid up } \\
\text { to } € 500000)\end{array}$ & $\begin{array}{l}\text { Decision not to raise objections } \\
\underline{\mathrm{IP} / 09 / 585}\end{array}$ & 15 April 2009 \\
\hline
\end{tabular}

\section{ITALY}

\begin{tabular}{|c|c|c|}
\hline $\begin{array}{l}\text { N 279/2009 - Temporary scheme (risk } \\
\text { capital) }\end{array}$ & $\begin{array}{l}\text { Decision not to raise objections } \\
\text { IP/09/825 }\end{array}$ & 20 May 2009 \\
\hline $\begin{array}{l}\text { N 266/2009 - Temporary scheme } \\
\text { (guarantees) }\end{array}$ & $\begin{array}{l}\text { Decision not to raise objections } \\
\text { IP/09/852 }\end{array}$ & 28 May 2009 \\
\hline $\begin{array}{l}\text { N 248/2009 - Temporary scheme (aid up to } € \\
500000 \text { ) }\end{array}$ & $\begin{array}{l}\text { Decision not to raise objections } \\
\text { IP/09/852 }\end{array}$ & 28 May 2009 \\
\hline $\begin{array}{l}\text { N 268/2009 - Temporary scheme } \\
\text { (subsidised interest rates) }\end{array}$ & $\begin{array}{l}\text { Decision not to raise objections } \\
\text { IP/09/857 }\end{array}$ & 29 May 2009 \\
\hline $\begin{array}{l}\text { N } 542 / 2009 \text { - Temporary scheme (aid for } \\
\text { green cars) }\end{array}$ & $\begin{array}{l}\text { Decision not to raise objections } \\
\text { IP/09/1581 }\end{array}$ & 26 October 2009 \\
\hline $\begin{array}{l}\text { N 706/2009 - Temporary scheme (aid up to } € \\
15000 \text { for the agricultural sector) }\end{array}$ & $\begin{array}{l}\text { Decision not to raise objections } \\
\text { IP/10/119 }\end{array}$ & 1 February 2010 \\
\hline
\end{tabular}




\section{LATVIA}

\begin{tabular}{|l|l|r|}
\hline $\begin{array}{l}\text { N 124/2009 - Temporary scheme (aid up to } € \\
500 \text { 000) }\end{array}$ & $\begin{array}{l}\text { Decision not to raise objections } \\
\text { IP/09/442 }\end{array}$ & 19 March 2009 \\
\hline N 139/2009 - Temporary scheme (guarantees) & $\begin{array}{l}\text { Decision not to raise objections } \\
\text { IP/09/626 }\end{array}$ & 22 April 2009 \\
\hline $\begin{array}{l}\text { N 670/2009 - Temporary scheme (guarantee } \\
\text { to JSC Liepajas Metalurgs) }\end{array}$ & $\begin{array}{l}\text { Decision not to raise objections } \\
\text { IP/09/1923 }\end{array}$ & 15 December 2009 \\
\hline $\begin{array}{l}\text { N 84/2010 - Temporary scheme (export-credit } \\
\text { insurance) }\end{array}$ & $\begin{array}{l}\text { Decision not to raise objections } \\
\underline{\text { P } / 10 / 718}\end{array}$ & 10 June 2010 \\
\hline
\end{tabular}

\section{LITHUANIA}

\begin{tabular}{|c|c|c|}
\hline $\begin{array}{l}\text { N 272/2009 - Temporary scheme (aid up to } € \\
500000 \text { ) }\end{array}$ & $\begin{array}{l}\text { Decision not to raise objections } \\
\underline{\text { IP/09/890 }}\end{array}$ & 8 June 2009 \\
\hline $\begin{array}{l}\text { N 523/2009 - Amendment } \\
\text { N 46/2010 - Amendment }\end{array}$ & $\underline{\mathbb{P} / 0}$ & $\begin{array}{r}13 \text { November } 2009 \\
10 \text { March } 2010\end{array}$ \\
\hline $\begin{array}{l}\text { N } 659 / 2009 \text { - Temporary scheme (export- } \\
\text { credit insurance) }\end{array}$ & $\begin{array}{l}\text { Decision not to raise objections } \\
\text { IP/09/1980 }\end{array}$ & 21 December 2009 \\
\hline $\begin{array}{l}\text { N 686/2009 - Temporary scheme (aid up to } € \\
15000 \text { for the agricultural sector) }\end{array}$ & $\begin{array}{l}\text { Decision not to raise objections } \\
\text { IP/10/118 }\end{array}$ & 1 February 2010 \\
\hline
\end{tabular}

\section{LUXEMBOURG}

\begin{tabular}{|c|c|c|}
\hline $\begin{array}{l}\text { N 99/2009 - Temporary scheme (aid up to } € \\
500000 \text { ) }\end{array}$ & $\begin{array}{l}\text { Decision not to raise } \\
\text { objections } \\
\text { IP/09/334 }\end{array}$ & 26 February 2009 \\
\hline $\begin{array}{l}\text { N 128/2009 - Temporary scheme } \\
\text { (guarantees) }\end{array}$ & $\begin{array}{l}\text { Decision not to raise } \\
\text { objections } \\
\text { IP/09/392 }\end{array}$ & 11 March 2009 \\
\hline $\begin{array}{l}\text { N 50/2009 - Temporary scheme (export- } \\
\text { credit insurance) }\end{array}$ & $\begin{array}{l}\text { Decision not to raise } \\
\text { objections } \\
\underline{\text { IP/09/603 }}\end{array}$ & 20 April 2009 \\
\hline
\end{tabular}

\section{MALTA}

\begin{tabular}{|l|l|r|}
\hline $\begin{array}{l}\text { N 118/2009 - Temporary scheme (aid up to } € \\
500000)\end{array}$ & $\begin{array}{l}\text { Decision not to raise } \\
\text { objections } \\
\underline{\text { PP/09/820 }}\end{array}$ & 18 May 2009 \\
\hline
\end{tabular}

\section{NetHERLANDS}

\begin{tabular}{|l|l|r|}
\hline $\begin{array}{l}\text { N 156/2009 - Temporary scheme (aid up to } \\
€ 500 \text { 000) }\end{array}$ & $\begin{array}{l}\text { Decision not to raise } \\
\text { objections } \\
\underline{\underline{I P} / 09 / 527}\end{array}$ & 1 April 2009 \\
\hline $\begin{array}{l}\text { N 409/2009 - Temporary scheme (export- } \\
\text { credit insurance) }\end{array}$ & $\begin{array}{l}\text { Decision not to raise } \\
\text { objections } \\
\text { IP } 14 / 209 / 1405\end{array}$ & 5 February 2010 \\
\hline
\end{tabular}




\section{POLAND}

N 408/2009 - Temporary scheme (aid up to $€$ $500000)$
Decision not to raise

objections

IP/09/1483

\section{Portugal}

N 13/2009 - Temporary scheme (aid up to $€$ $500000)$

\begin{tabular}{l|l|}
$\begin{array}{l}\text { Decision not to raise } \\
\text { objections } \\
\text { IP/09/71 }\end{array}$ & 19 January 2009 \\
\hline
\end{tabular}

\section{ROMANIA}

\begin{tabular}{|c|c|c|}
\hline $\begin{array}{l}\text { N 286/2009 - Temporary scheme (guarantees) } \\
\text { N173/2010 - Amendment }\end{array}$ & $\begin{array}{l}\text { Decision not to raise } \\
\text { objections } \\
\text { IP/09/882 }\end{array}$ & $\begin{array}{l}5 \text { June } 2009 \\
24 \text { June } 2010\end{array}$ \\
\hline $\begin{array}{l}\text { N } 547 / 2009 \text { - Temporary scheme (aid up to } € \\
500 \text { 000) }\end{array}$ & $\begin{array}{l}\text { Decision not to raise } \\
\text { objections } \\
\text { IP/09/1876 }\end{array}$ & 3 December 2009 \\
\hline $\begin{array}{l}\text { N 478/2009 - State guarantee in favour of Ford } \\
\text { Romania }\end{array}$ & $\begin{array}{l}\text { Decision not to raise } \\
\text { objections } \\
\text { IP/09/1711 }\end{array}$ & 13 November 2009 \\
\hline
\end{tabular}

\section{SLOVAKIA}

\begin{tabular}{|l|l|r|}
\hline $\begin{array}{l}\text { N 222/2009 - Temporary scheme (aid up to } € \\
500000)\end{array}$ & $\begin{array}{l}\text { Decision not to raise } \\
\text { objections } \\
\text { IP/09/680 }\end{array}$ & 30 April 2009 \\
N 711/2009 - Amendment & 2 February 2010 \\
\hline $\begin{array}{l}\text { N 707/2009 - Temporary scheme (aid up to } € 15 \\
000 \text { for the agricultural sector) }\end{array}$ & $\begin{array}{l}\text { Decision not to raise } \\
\text { objections } \\
\text { IP/10/234 }\end{array}$ & 4 March 2010 \\
\hline
\end{tabular}

\section{SLOVENIA}

\begin{tabular}{|l|l|r|}
\hline NN 34/2009 - Temporary scheme (guarantees) & $\begin{array}{l}\text { Decision not to raise } \\
\text { objections } \\
\text { IP/09/917 }\end{array}$ & 12 June 2009 \\
N $105 / 2010$ - Amendment & 16 April 2010 \\
\hline $\begin{array}{l}\text { N 228/2009 - Temporary scheme (aid up to } € 500 \\
000)\end{array}$ & $\begin{array}{l}\text { Decision not to raise } \\
\text { objections } \\
\text { IP/09/918 }\end{array}$ & 12 June 2009 \\
\hline $\begin{array}{l}\text { N 713/2009 - Temporary scheme (export-credit } \\
\text { insurance) }\end{array}$ & $\begin{array}{l}\text { Decision not to raise } \\
\text { objections } \\
\text { IP/10/282 }\end{array}$ & 16 March 2010 \\
\hline
\end{tabular}


SPAIN

\begin{tabular}{|l|l|r|}
\hline $\begin{array}{l}\text { N 140/2009 - Temporary scheme (aid for green } \\
\text { cars) }\end{array}$ & $\begin{array}{l}\text { Decision not to raise } \\
\text { objections } \\
\text { IP/09/499 }\end{array}$ & 29 March 2009 \\
\hline $\begin{array}{l}\text { N } 307 / 2009-\text { Temporary scheme (aid up to } € \\
500000)\end{array}$ & $\begin{array}{l}\text { Decision not to raise } \\
\text { objections } \\
\text { IP/09/889 }\end{array}$ & 8 June 2009 \\
\hline N $68 / 2010$ - Temporary scheme (guarantees) & $\begin{array}{l}\text { Decision not to raise } \\
\text { objections }\end{array}$ & 30 March 2010 \\
N 157/2010 - Amendment & 8 June 2010 \\
\hline
\end{tabular}

\section{SWEDEN}

\begin{tabular}{|l|l|c|}
\hline $\begin{array}{l}\text { N 80/2009 - State guarantees in favour of Volvo } \\
\text { cars }\end{array}$ & $\begin{array}{l}\text { Decision not to raise } \\
\text { objections } \\
\text { IP/09/879 }\end{array}$ & 5 June 2009 \\
\hline $\begin{array}{l}\text { N } 605 / 2009 \\
\text { insurance) }\end{array}$ & $\begin{array}{l}\text { Decision not to raise } \\
\text { objections } \\
\text { IP/09/1819 }\end{array}$ & 25 November 2009 \\
\hline N 541/2009 - State guarantee in favour of Saab & $\begin{array}{l}\text { Decision not to raise } \\
\text { objections } \\
\text { IP/10/139 }\end{array}$ & 8 February 2010 \\
\hline
\end{tabular}

\section{UNITED KINGDOM}

\begin{tabular}{|l|l|c|}
\hline $\begin{array}{l}\text { N 43/2009 - Temporary scheme (aid up to } € 500 \\
000)\end{array}$ & $\begin{array}{l}\text { Decision not to raise } \\
\text { objections } \\
\text { IP/09/215 }\end{array}$ & F February 2009 \\
\hline N 71/2009 - Temporary scheme (guarantees) & $\begin{array}{l}\text { Decision not to raise } \\
\text { objections } \\
\text { IP/09/333 }\end{array}$ & 27 February 2009 \\
\hline $\begin{array}{l}\text { N 72/2009 - Temporary scheme (to businesses } \\
\text { producing green products) }\end{array}$ & $\begin{array}{l}\text { Decision not to raise } \\
\text { objections } \\
\text { IP/09/333 }\end{array}$ & 15 May 2009 \\
\hline $\begin{array}{l}\text { N 257/2009 - Temporary scheme (subsidised } \\
\text { interest rates) }\end{array}$ & $\begin{array}{l}\text { Decision not to raise } \\
\text { objections } \\
\text { IP/09/793 }\end{array}$ & 30 March 2010 \\
\hline $\begin{array}{l}\text { N 71/2010 - Temporary scheme (aid up to } € 15000 \\
\text { for the agricultural sector) }\end{array}$ & $\begin{array}{l}\text { Decision not to raise } \\
\text { objections } \\
\text { IP/10/390 }\end{array}$ & \\
\hline
\end{tabular}

Cases currently under formal investigation procedure - cases falling under the Temporary framework (in-depth investigation under the EC Treaty's rules on state aid)

\begin{tabular}{|l|l|l|l|}
\hline Country & Type of measure / Beneficiary & $\begin{array}{l}\text { Date of decision } \\
\text { regarding the } \\
\text { opening of formal } \\
\text { investigation }\end{array}$ & \\
\hline Romania & $\begin{array}{l}\text { C } 36 / 2009-\text { State guarantee in } \\
\text { favour of Oltchim }\end{array}$ & $\begin{array}{l}19 \text { November } \\
2009 \\
\mathrm{IP} / 09 / 1748\end{array}$ & $\begin{array}{l}\text { Case under } \\
\text { assessment }\end{array}$ \\
\hline
\end{tabular}

